Document downloaded from:

http://hdl.handle.net/10251/103995

This paper must be cited as:

Jorge Amorim, R.; Novella Rosa, R.; García Martínez, A.; Molina, S. (2017). Study on LTC for light duty engines Part 2 Spray enhancements. Fuel. 193:206-219. doi:10.1016/j.fuel.2016.12.050

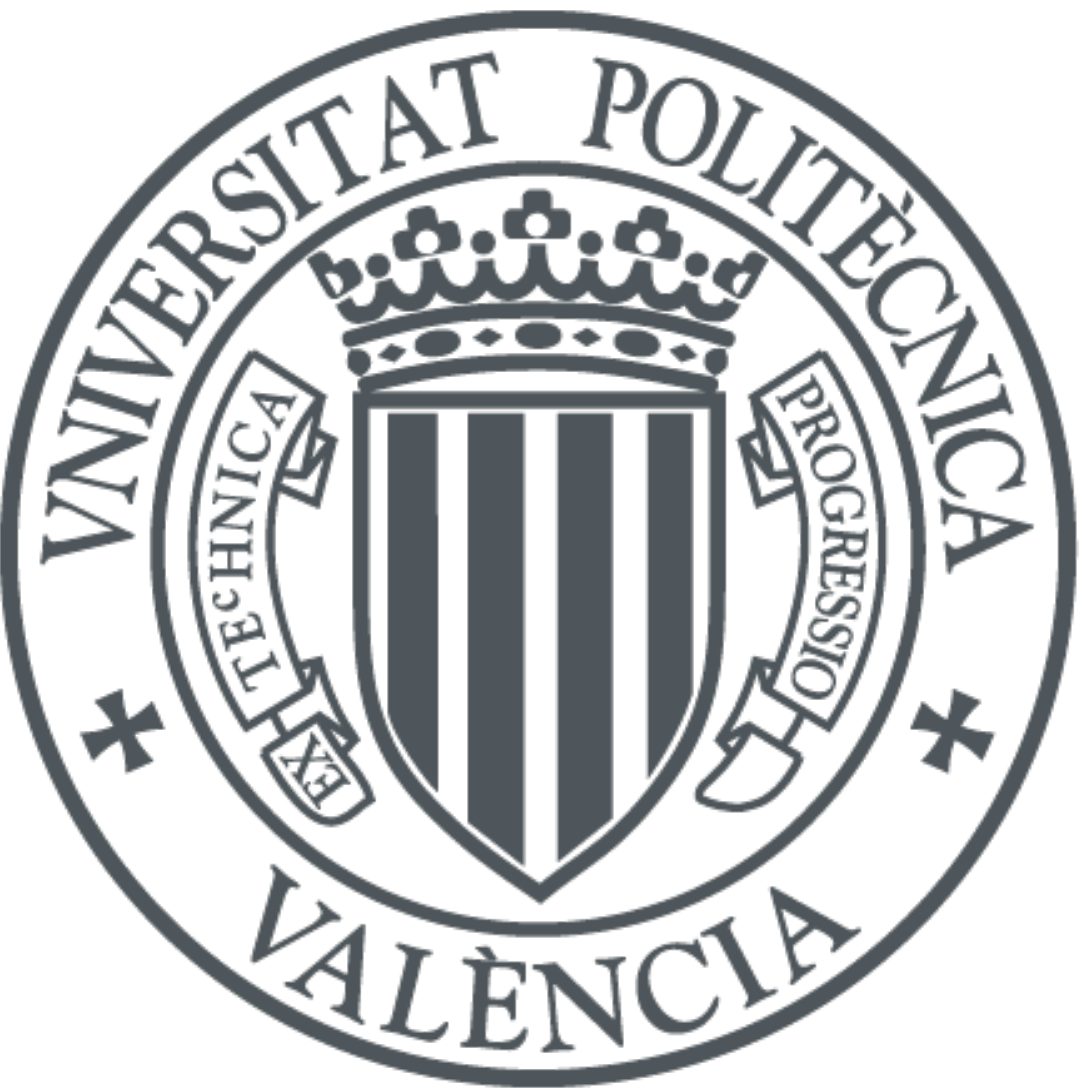

The final publication is available at

http://doi.org/10.1016/j.fuel.2016.12.050

Copyright Elsevier

Additional Information 


\section{Study on LTC for light duty engines - Part 2 - Spray}

\section{enhancements}

Rogério J. Amorim (*),

5 Av. Dom José Gaspar, 500, Coração Eucarístico, Belo Horizonte - Minas Gerais (Brasil)

$15\left(^{*}\right)$ Corresponding author: Rogério Amorim, e-mail: rogerioamorim@pucminas.br, Tel: +55 31 99801-1405 Fax: $16+55313319-4911$ 
17 DEFINITIONS, ACRONYMS, ABBREVIATIONS

$18(A / F)_{\text {STOICH }}$ Stoichiometric Air-Fuel ratio

$19 \mathrm{~A} / \mathrm{F} \quad$ Air-Fuel ratio

20 aTDC After Top Dead Center

$21 \mathrm{C}_{\mathrm{a}} \quad$ nozzle orifice area contraction coefficient

22 CAD Crankshaft Angle Degree

23 CFD Computational Fluid Dynamics

$24 \mathrm{CO}$ Carbon Monoxide

$25 \mathrm{CO}_{2} \quad$ Carbon Dioxide

26 CR Compression ratio

$27 \mathrm{dBa} \quad$ decibel

28 DIES Direct Injection Engine Simulation software

$29 \quad d_{\text {nozzle }} \quad$ nozzle orifice diameter

30 EGR Exhaust Gas Recirculation

31 EU European Union

32 FC Fuel consumption

33 FSN Filter Smoke Number

$34 \quad H \quad$ Lift-off length

35 HC Hydrocarbons

36 HRL Heat Release Law

37 HSDI High-speed Direct Injection

38 IMEP Indicated Mean Effective Pressure

39 IP Injection Pressure

40 LL Liquid Length

41 LTC Low Temperature Combustion

42 mair intake air mass flow

$43 m_{E G R} \quad$ EGR mass flow

$44 m_{f} \quad$ fuel mass flow per cycle

$45 \quad$ mint intake total air mass flow

$46 \quad \mathrm{NO} \quad$ Nitrogen Oxide

$47 \quad \mathrm{O}_{2} \quad$ Oxygen

48 OEM Original Equipment Manufacturer

49 PAH Polycyclic Aromatic Hydrocarbons

50 PCI Premixed Compression Ignition 
$51 \quad p_{\text {int }} \quad$ intake air pressure

52 ppm parts per million

53 RoHR Rate of Heat Release

$54 \mathrm{rpm}$ rotations per minute

55 SFC Specific Fuel Consumption

56 SoE Start of Energizing

57 SoI Start of Injection

$58 T_{A D} \quad$ Adiabatic Flame Temperature

$59 T_{A d \_M a x}$ Maximum Adiabatic Flame Temperature

$60 T_{A M B} \quad$ ambient air temperature

$61 \tan (\theta / 2) \quad$ jet spreading half-angle

62 TDC Top Dead Center

$63 t_{i n j} \quad$ Injection Duration

$64 \quad T_{\text {int }} \quad$ intake air temperature

$65 U$ Injection Velocity

$66 \mathrm{XO}_{2} \quad$ Oxygen concentration

$67 X_{O 2 \_a i r}$ ambient air volumetric oxygen concentration

$68 X_{O 2}$ int intake air volumetric oxygen concentration

$69 Z_{s t} \quad$ stoichiometric fuel mixture fraction

$70 \quad \rho_{\text {air }} \quad$ in-cylinder air density

$71 \rho_{f} \quad$ fuel density

$72 \tau_{i g} \quad$ Ignition Delay

$73 \Phi_{H} \quad$ Equivalence ratio at the lift-off length cross-section 
ABSTRACT:

This paper presents the $2^{\text {nd }}$ part of a study on low temperature diffusive combustion in a small HSDI (High Speed Direct Injection) engine with the objective of avoiding simultaneously NOx and soot formation, aiming to extend the range of operation conditions where this combustion strategy has been achieved and. Also, it was intended to reduce $\mathrm{CO}$ and $\mathrm{HC}$ emissions, considered very high in the 1st part of the tests. New hardware configuration was chosen in order to improve air entrainment in the lift-off length such as increasing injection pressure, reducing fuel injection rate and nozzle hole diameter. Also, a parametric study on the behavior of in-cylinder air thermodynamic characteristics towards the diffusion-flame low temperature combustion was also carried out in order to evaluate the important aspects of each one and observe how the LTC range has been extended.

The strategy is based mainly in a significant reduction of the equivalence ratio at the lift-off length cross section and the combustion temperature, maintaining the conventional mixing controlled diesel jet structure. In this $2^{\text {nd }}$ part of the study, injection pressure was increased and new nozzles with reduced holes were used to enhance air entrainment and the injection rate was reduced to extend the duration of diffusion-flame combustion phase.

The new proposal allowed extending Diffusion-flame LTC range, being possible to achieve this combustion modality with higher air temperature which lead to considerable reduction in $\mathrm{HC}, \mathrm{CO}$ and combustion noise while NOx and Soot remained insignificant.

KEYWORDS: LTC; Diffusion-flame Combustion; Light duty engine; Diesel engine; Diffusion flame 
Diesel engine technology development, much of them regulatory driven, was the main responsible for the increasing diesel market share from around 20\% in 1995 to more than 50\% in 20011 in Europe, and the total EU fleet from $12 \%$ to $35 \%$. The increase market share is mostly attributed to tax incentives for diesel fuel, tax advantages to support Diesel-fueled car sales and provisions to taken by the OEM's in order to invest in Diesel engine development [1,2]. A very strict regulatory is going to be effective soon in Europe, USA and Japan, a very exigent market in terms of reliability, performance and cleaner vehicles, and a great demand for fuel economy engines turned into the great challenges for the diesel engine manufacturers. Diesel developers have reacted using ultimate technology such as advanced injection systems, EGR (Exhaust Gas Recirculation) control, downsizing and hybridization, etc. $[3,4]$

In a classic definition, a diffusion flame is considered a flame which fuel and oxidizer are initially separated. For a Diesel engine, burning rate is much faster than the mixing rate, so the mixing controls the combustion process. Since the mixing process depends on the injection event, for a diffusion flame, combustion and injection events must happen simultaneously. If the injection ends prior than the start of combustion, this combustion process is considered a premixed combustion, even if it is not homogeneous. [5]

Combustion process in a Diesel engine is a very complex phenomenon. In 1997, Dec proposed a new Diesel spray conceptual model which became a reference on diesel combustion and on which the development of this work is based. This work is based initially on the Diesel spray conceptual model introduced by him, which became a standard on diesel combustion. In this model, he presented a schematic of diesel combustion including the zones where NOx (Nitrogen Oxide) and soot were initially formed. [6,7]

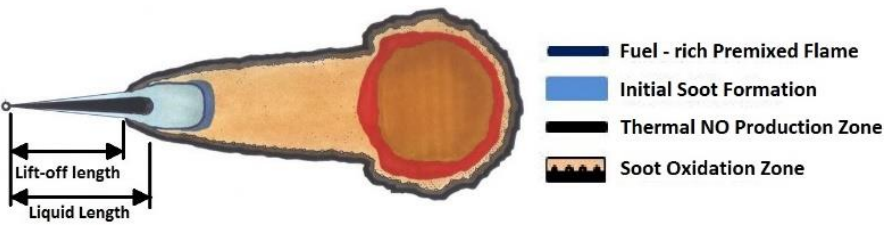

Figure 1. Schematic view of Diesel spray conceptual model proposed by Dec. [6]

Figure 1 presents the conceptual model proposed by Dec. From the injector nozzle until the beginning of the flame, the fuel entrains some air that surrounds the jet (in light blue). Fuel-air mixture reaches the auto-ignition temperature and first reactions start in the fuel-rich premixed flame zone (dark blue). In this zone, an almost ideal environment for soot formation is created by the high ambient temperature and the fuel-rich mixture. These particles tend to enlarge (yellow) as they go towards the flame vortex where the largest soot particles are found (red zone). At the surroundings of the flame, the remaining fuel burns in contact with the external air oxygen. The mixing-controlled diffusion flame at the periphery of the jet significantly increases flame temperature and provides thermal NOx formation. Also, in the diffusion flame, soot particles formed inside the jet might be oxidized by the effects of high temperatures (in black) [6].

Some investigations were elaborated on conceptual models of reactive free diesel sprays and those models have been improved continuously due to the use of more modern technology applied to the reactive and non-reactive spray visualization. [6,8-14] Those visualizations permitted to identify zones where cool flames, soot precursors and high temperature reactions happen. Also, some investigations have been carried out to identify different zones where $\mathrm{NOx}_{\mathrm{x}}$, soot precursors or soot are found in the flame and where they are first formed. Therefore, the influence of wall-jet and jet-jet interactions was studied to develop a combustion structure model. $[15,16]$ Although they were of vital importance, it is important to point-out that those works were carried out in a constant volume vessel to study the spray behavior independently of the engine dynamics.

Extended Zeldovich mechanism describes the chemistry of the NOx formation process that consists of chain reactions involving $\mathrm{O}$ and $\mathrm{N}$ atoms. Thermal $\mathrm{NOx}$ formation is considered insignificant in local ambient 
temperatures below $2000 \mathrm{~K}$ and mostly happens in near-stoichiometric mixing-controlled reaction zones in the combustion chamber. $[17,18]$

Moreover, engine-out soot is the final result of a competition between soot formation and soot oxidation. Soot formation origins from a chemical process called Pyrolysis when soot precursors, PAH (polycyclic aromatic hydrocarbons) and acetylenes, are formed due to changes of the fuel organic compounds molecular structure. In the sequence, Nucleation, or soot particle inception, takes place in a temperature range from 1400 to $1600 \mathrm{~K}$, consisting of radical additions of small hydrocarbons to larger aromatic molecules. The next step in soot formation is the mass addition to the surface of a nucleated soot particle, known as Surface growth. Lastly, two processes of particle association happen simultaneously: Coalescence and agglomeration, forming new bigger particles with spherical shapes or chain-like structure. In fact, soot is really formed during the nucleation. The other processes can be described only as enlarging effects defining final soot particle size. On the contrary, soot oxidation is the conversion of carbon or hydrocarbons to combustion products, and, once the carbon present in the fuel is partially involved in oxidation to CO (Carbon Monoxide), it will no longer form soot. In diffusion flames, soot formation rate and soot oxidation rate increase with temperature. Soot formation starts above $1400 \mathrm{~K}$ whereas its oxidation ceases below $1300 \mathrm{~K}$. Consequently, combustion temperature is the most influent parameter in the process. [12]

Basically, soot formation in a diesel jets depends on three factors: equivalence ratio at the lift-off length $\left(\Phi_{H}\right)$, residence time of the fuel inside the flame and local temperature inside the flame. On the other hand, soot oxidation depends mainly on the combustion process temperature. [13]

In addition, combustion temperatures must be reduced to avoid thermal NOx formation. However, the observed effect of the combustion temperature reduction is the immediate extinction of soot oxidation process leading to a substantial engine-out soot increase. Nevertheless, a possibility of reducing $\mathrm{NOx}$ and engine-out soot emissions simultaneously might occur by reducing combustion temperature so that $\mathrm{NOx}$ and soot formation would be avoided. [9]

A viable and novel solution is the Diffusion-flame Low Temperature Combustion (LTC), presented as the previous part of this investigation, reduces $\mathrm{NO}_{\mathrm{x}}$ and soot formations to negligible amounts, preserving the mixing-controlled diesel jet structure [19]. The concept is based on a significant reduction of the combustion temperature and the equivalence ratio at the lift-off length cross section. This zero-NOx, non-sooting combustion strategy was first attained using a free-jet configuration in a constant-volume vessel. [20] Afterwards, the Diffusion-flame LTC concept was successfully transferred to a real engine, as seen in the previous work. In that investigation, although soot and NOx levels were negligible, $\mathrm{CO}$ and $\mathrm{HC}$ (Hydrocarbons) emissions were inacceptable. Also, IMEP (Indicated Mean Effective Pressure) presented a reduction around 10\% due to the combustion process deterioration [19].

It is important to highlight that Diffusion-flame LTC presents other advantages such as not having problems with combustion ignition control and low combustion noise if compared to regular mixing-controlled combustion process [19]. However, in a real engine situation, in-cylinder gas thermodynamic characteristics vary cycle-bycycle and according to the operating condition, which could be a major challenge to obtain this combustion modality [21]. Moreover, lift-off length and the equivalence ratio at this point can be affected by jet-jet and jetwall interactions. For longer lift-off lengths, wall-impingement is likely to happen and might cause undesirable increase in $\mathrm{HC}$ and $\mathrm{CO}$ emissions. Finally, it is necessary to use very high intake boost pressures to achieve very low oxygen concentrations (very high EGR rates) with suitable values for A/F (Air/Fuel ratio) in order to reduce substantially combustion temperatures to avoid NOx and Soot formation.

\section{OBJECTIVES}

The previous part of this study succeeded in attaining Diffusion-flame LTC in a DI Diesel engine although it only happened for engine operating condition with a very low volumetric oxygen concentration of $9 \%$, high air density of $40 \mathrm{~kg} / \mathrm{m}^{3}$ and cooled intake air temperature (air + EGR) of $40^{\circ} \mathrm{C}$. This is considered an extreme and not realistic 
operational condition. However, very high $\mathrm{CO}$ and $\mathrm{HC}$ emissions were observed associated to a significant reduction in IMEP [19].

The main objective of this study is to extend Diffusion-flame LTC range using a small HSDI diesel engine in order to avoid both $\mathrm{NOx}$ and soot formation by reducing $\mathrm{O}_{2}$ concentration and equivalence ratio at the same time. The extension of the range would be fundamental to allow this combustion strategy to work in less several operational conditions (e.g., higher $T_{\text {int }}$ and lower EGR rate) in which $\mathrm{HC}$ and $\mathrm{CO}$ emissions are reduced and the penalty on IMEP are less important, demonstrating its feasibility to be applied on the market in a near future.

This combustion strategy is studied in a real engine in order to:

- investigate the possibility of extending Diffusion-flame LTC range;

- study the influence of different parameters separately and their interactions;

- identify any restriction and opportunity on applying and/or extend this concept in a HSDI engine.

\section{METHODOLOGY}

This section elaborates the experimental facility and the development of the test plan through the engine maps used in the investigation.

\subsection{EXPERIMENTAL FACILITY AND TOOLS}

The engine used was a single cylinder, HSDI diesel engine with high capability of controlling engine parameters and measurement accuracy. For this engine, boost pressure could be set up independently of the engine operational condition, presenting compatibility between high intake boost pressures and very high EGR rates. The engine main characteristics are shown in table 1.

Table 1. Engine characteristics

\begin{tabular}{ll}
\hline Characteristic & Description \\
\hline CR & $15: 1$ \\
Displacement & $0.399 \mathrm{dm}^{3}$ \\
Bowl diameter & $46.35 \mathrm{~mm}$ \\
Nozzle & $6 \times 129 \mu \mathrm{m}$ \\
\hline
\end{tabular}

The engine was installed in a fully equipped test cell, with all the auxiliary devices required for operating and controlling the facility. It was designed to work with high concentrations of cooled EGR (up to $70 \%$ ) with no water condensation in the intake, being possible to achieve EGR+air intake temperatures in the order of $40^{\circ} \mathrm{C}$. The EGR flow has its temperature controlled in a cooler and then, in a settling chamber, the condensed water is drained to avoid water accumulation in the intake system.

For in-cylinder pressure measurement, a KISTLER 4076A pressure transducer and a KISTLER 4618A amplifier were used. A total of 50 consecutive engine cycles per each tested point was acquired, averaged and filtered to avoid cycle-by-cycle variations during engine test. An in-house combustion diagnostic software, CALMEC, was used for heat release law calculation. The 2-zone, 0-D model, based on the first law of thermodynamics applied to a diesel engine and adiabatic flame temperature, assumes constant pressure and temperature along the combustion chamber, being possible to calculate unburned and burned gas temperatures considering that the gases inside the cylinder could be separated in 2 zones. [22-24]. Combustion noise was calculated by CALMEC by means of an estimation proposed by Payri et al. using an in-cylinder pressure trace decomposition technique. The 
pressure signal is converted with a Fast Fourier Transform in a cylinder pressure spectrum. Then, using a filter (U-filter), the pressure spectrum is attenuated to a frequency range that is audible to human ear and converted to dBa. $[25,26]$.

The actual fuel injection rate was measured by an IAV-EVI injection analyzer and calculated using the equation by Bosch [27]. In order to evaluate the non-reactive diesel spray development inside the cylinder, an in-house CFD tool called DIES (Direct Injection Engine Simulation) predicts the behavior of non-reactive diesel sprays according to operational conditions such as air density, temperature, injection pressure and nozzle characteristics when introducing the injection rate, engine geometry and in-cylinder ambient conditions [28].

Exhaust gases were analyzed by a HORIBA 7100D which is able to measure $\mathrm{HC}, \mathrm{CO}, \mathrm{CO}_{2}, \mathrm{NO}$ and $\mathrm{O}_{2}$. In order to increase the quality of data, measurements were carried out using samples collected during 60 seconds. All emission results obtained in ppm during the tests were converted to specific values in $\mathrm{g} / \mathrm{kg}$ fuel. Soot emissions were measured with an AVL 415 smokemeter, providing results directly in FSN (Filter Smoke Number) averaged from 3 consecutive measurements under the same operating conditions. The FSN value was converted into $\mathrm{mg} / \mathrm{m}^{3}$ by means of the correlation presented by Christian et al. [29]

The measurement uncertainties were defined according to the equipment calibration and statistical procedures [30]. The uncertainties for each parameter is presented in Table 2 and they are expressed in a percentage of the measured value.

Table 2 Measurement System Uncertainty

\begin{tabular}{lll}
\hline Parameter & Equipment & Uncertainty \\
\hline NOx, CO, CO2, HC & Horiba 7100D & $\pm 3 \%$ \\
Soot & AVL 415 & $\pm 3 \%$ \\
Fuel mass flow & AVL KMA4000 & $\pm 0.1 \%$ \\
Air mass flow & Elster RVG G-65 & $\pm 2 \%$ \\
In-cylinder pressure & Kistler 6055 & $\pm 0.1 \%$ \\
\hline
\end{tabular}

Besides the conventional 6 x $129 \mu \mathrm{m}, 2$ new injector nozzles have been developed and constructed for this study, both with reduced fuel injection rate around $25 \%$ if compared to the original one. The description of the two new nozzles can be found in table 3 :

Table 3 Injector nozzle characteristics

\begin{tabular}{lllll}
\hline Characteristics & Unity & Nozzle 1 & Nozzle 2 & Nozzle 3 \\
\hline Orifice number & {[]} & 6 & 6 & 9 \\
Orifice diameter & {$[\mu \mathrm{m}]$} & 129 & 101 & 83 \\
Hydraulic delivery rate & {$\left[\mathrm{cm}^{3} / 30 \mathrm{~s}\right]$} & $284-295$ & $187-195$ & $187-195$ \\
Injection angle & {$\left[{ }^{\circ}\right]$} & 150 & 150 & 150 \\
\hline
\end{tabular}

\subsection{ENGINE MAP}

The engine maps are very important as it can correlate various engine controllable operating parameters, such as intake air pressure, $A / F$ and EGR rate to in-cylinder ambient conditions, like $\mathrm{O}_{2}$ concentration and air density. This method was developed to control a new combustion approach with oxygen concentration. [19,31,32]. Firstly, 
engine test load condition is defined through fuel consumption per cycle $\left(m_{f}\right)$. It can be directly linked to intake air mass flow $\left(m_{\text {in }}=m_{a i r}+m_{E G R}\right)$ in function of $A / F$ and EGR ratio by the equation:

$$
A / F=(1-E G R) \cdot m_{\text {int }} / m_{f}
$$

where $m_{\text {int }}$ is intake total air mass flow and $\mathrm{m}_{\mathrm{f}}$ is fuel mass flow. For the hypothesis of complete combustion, it is possible to represent the $\mathrm{O}_{2}$ volumetric concentration $\left(X_{O 2}\right.$ int $)$ isoline by:

$$
\text { Xo2_int }=\text { XO2_air } \cdot\left(1-E G R \cdot(A / F)_{\text {STOICH }} /(A / F)\right)
$$

where $\mathrm{XO2}_{\text {_int }}$ and $\mathrm{XO2}_{\mathrm{O} \text { air }}$ are intake and ambient air volumetric $\mathrm{O}_{2}$ concentrations, respectively, and $(\mathrm{A} / \mathrm{F})_{\text {STOICH }}$ is the stoichiometric air fuel ratio. Thus, a $2^{\text {nd }}$ hypothesis that at constant values of intake pressure and temperature, volumetric efficiency and gas constant remain unchanged, independently of EGR ratio, is accepted. Once the engine map for a specific engine load is defined, engine geometry and engine operating conditions, such as clearance volume, volumetric efficiency, engine speed and intake air temperature $\left(T_{\text {int }}\right)$, can be associated to intake total air mass flow to obtain values for air density $\left(\rho_{\text {air }}\right)$ and intake air pressure $\left(p_{\text {int }}\right)$.

The engine map calculated for $T_{\text {int }}=75^{\circ} \mathrm{C}$ used in this investigation is shown in figure 2. It is noticeable that air density and intake air pressure are parallel. In other words, air density is easily controlled by changing intake air pressure.

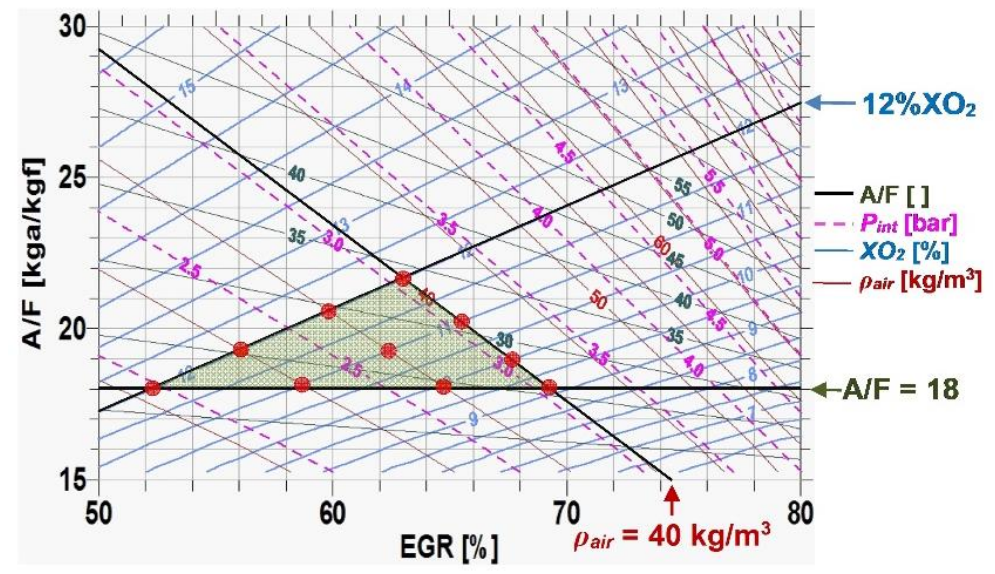

Figure 2. Engine map calculated for intake air temperature of $75^{\circ} \mathrm{C}$. Light blue lines are volumetric $\mathrm{O}_{2}$ concentration, pink lines are intake air pressure and red lines are air density and green lines are air-fuel ratio. Note that air density and intake air pressure are parallel lines. The green triangle is the limited area designed to be the test plan and the red dots are the points to be tested.

\subsection{ENGINE TEST PLAN}

In 1998, Siebers investigated the influence of various parameters on liquid length (Figure 1) [33]. Moreover, García proposed an empirical equation that associated the liquid length to nozzle orifice diameter $\left(d_{\text {nozzle }}\right)$, air temperature $\left(T_{A M B}\right)$ and air density $\left(\rho_{\text {air }}\right)[34]$ :

$$
L L=\left(d_{\text {nozzle }} / 150\right) \cdot 7.2455 \times 10^{5} \cdot T_{A M B^{-1.269}} \cdot \rho_{a i r}{ }^{-0.53}
$$

Reducing the liquid-phase and increasing lift-off length (Figure 1) would increase significantly the amount of entrained air downstream the lift-off length. [35] Also, an equivalence ratio value at the lift-off cross section around or below two was affirmed to reduce soot formation to negligible amounts [36]. In more recent studies, the effects of ambient conditions, nozzle orifice diameter, injection pressure and oxygenated fuels on lift-off length and global air entrainment were measured. Based on those, Siebers, Higgins and Picket developed two equations to estimate lift-off length $(H)$ and equivalence ratio at the lift-off $\left(\Phi_{H}\right)$, respectively: 


$$
\begin{aligned}
& H=7.04 \times 10^{8} \cdot T_{A M B^{-3.74}} \cdot \rho_{a i r}{ }^{-0,85} \cdot d_{n o z z l e} 0.34 \cdot U \cdot Z_{s t}{ }^{-1}
\end{aligned}
$$

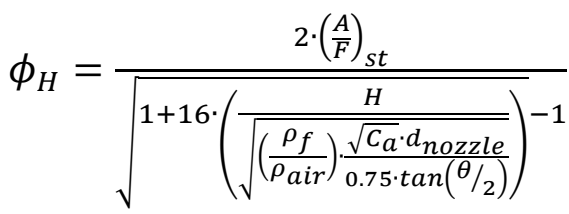

where $U$ is injection velocity, $Z_{s t}$ is stoichiometric fuel mixture fraction, $\rho_{f}$ is fuel density, $\mathrm{C}_{\text {a }}$ is the nozzle hole area contraction coefficient and $\tan (\theta / 2)$ is the jet spreading half-angle $[16,20,35,36]$. Pickett, Siebers and Idicheria also researched into the relationship between ignition processes and the lift-off. They observed that there was not a general rule, but there was a trend that the longer the lift-off the longer the ignition delays $\left(\tau_{i g}\right)$. They affirmed that ignition delay tends to increase by decreasing temperature, air density and $\mathrm{O}_{2}$ concentration:

$$
\tau_{i g} \propto e^{\left(1 / T_{A M B}\right)} \cdot \rho_{\text {air }}{ }^{n} \cdot Z_{s t}^{m}
$$

where the value of $n \approx-1.3$ and $m \approx-1.0$ for diesel fuel. [37]

Each parameter presents a different effect on diesel jet according to the several studies carried out by Sandia National Laboratory in a constant volume vessel with controlled ambient conditions. In the Table 4, the parameter effects on the spray are exposed. The Trend is the parameter change that is adopted in this study that leads to spray enhancements or enhances Diffusion-flame LTC conditions. The arrows indicate if the trend or the other spray characteristics increases $(\uparrow)$ or decreases $(\downarrow)$ :

\begin{tabular}{|c|c|c|c|c|c|}
\hline Parameter & Trend & $\mathbf{L L}$ & $\mathbf{H}$ & $\Phi_{H}$ & Observations \\
\hline Air Density & $\uparrow$ & $\downarrow$ & $\downarrow$ & $\begin{array}{l}\text { Global net result is a } \\
\text { slight increment }\end{array}$ & 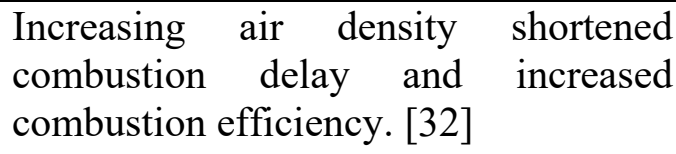 \\
\hline $\begin{array}{l}\text { Air } \\
\text { temperature }\end{array}$ & $\downarrow$ & $\uparrow$ & $\uparrow$ & $\downarrow$ & $\begin{array}{l}\text { It reduces the whole cycle temperature } \\
\text { that can lead to a reduction in NOx } \\
\text { formation and affect soot formation and } \\
\text { oxidation rates. }\end{array}$ \\
\hline $\begin{array}{l}\mathrm{O}_{2} \\
\text { Concentration }\end{array}$ & $\downarrow$ & - & $\uparrow$ & $\begin{array}{l}\text { The rate of air } \\
\text { entrainment decreases } \\
\text { so the final net effect is } \\
\text { a constant amount of } \\
\text { entrained air. }\end{array}$ & $\begin{array}{l}\text { The dilution slows } \mathrm{O}_{2} \text {-fuel mixture ratio } \\
\text { that has great influence in the flame } \\
\text { temperature, directly correlated to soot } \\
\text { formation and oxidation and } \mathrm{NO} x \\
\text { formation. }[12,33-36]\end{array}$ \\
\hline $\begin{array}{l}\text { Injection } \\
\text { Pressure }\end{array}$ & $\uparrow$ & - & $\uparrow$ & $\downarrow$ & $\begin{array}{l}\text { Improved air fuel mixing properties can } \\
\text { help reduce } \mathrm{HC} \text { and } \mathrm{CO} \text { emissions } \\
{[12,38] \text {. }}\end{array}$ \\
\hline $\begin{array}{l}\text { Orifice } \\
\text { diameter }\end{array}$ & $\downarrow$ & $\downarrow$ & $\downarrow$ & $\downarrow$ & $\begin{array}{l}\text { The amount of air entrained } \\
\text { downstream the lift-off cross section } \\
\text { decreases, but injection rate is reduced } \\
\text { more intensively. Thus, air entrainment } \\
\text { per mass unit increases and equivalence } \\
\text { ratio at the lift-off length cross section } \\
\text { decreases. [12,38] }\end{array}$ \\
\hline
\end{tabular}

Table 4: Parameter Effects on the Diesel Spray 
The extensive use of EGR combined with very high intake boost pressures was studied by Noehre et al and Colban et al. [39,40] However, they did not have the compromise to obtain strictly a Diffusion-flame LTC. They observed that reducing intake $\mathrm{O}_{2}$ concentration to very low levels at high air densities could lower soot and $\mathrm{NOx}$ simultaneously. The reduction in combustion temperatures caused by lower $\mathrm{O}_{2}$ concentration avoids soot and NOx formation. On the contrary, CO, HC and SFC (Specific Fuel Consumption) presented considerable losses.

The test plan was developed to obtain three fundamental purposes: (1) Diffusive combustion; (2) LTC and (3) The lowest possible equivalence ratio at the lift-off length cross section. Ambient air density, $\mathrm{A} / \mathrm{F}$ and $\mathrm{O}_{2}$ concentration operating range were determined based on: (a) Engine operating conditions was $2250 \mathrm{rpm}$, midload, single injection with constant fuel mass flow of $19 \mathrm{mg} / \mathrm{cc}$ and targeting $9.0 \mathrm{bar}$ IMEP (not fixed). Fuel injection SoE (start of energizing) was -10.0 CAD aTDC, equivalent to a SoI (start of injection) at - 5.0 CAD aTDC due to the fuel system injection delay. (b) The A/F value could not be lower than 18 to avoid excessive $\mathrm{HC}$ and CO. (c) Air density could not be higher than $40 \mathrm{~kg} / \mathrm{m}^{3}$ because of equipment intake pressure safety restrictions. (d) Once $\mathrm{XOZ}_{-}$int would not affect equivalence ratio at the lift-off length, it could be set as the lowest range possible in order to obtain a very low combustion temperature, aiming to avoid both $\mathrm{NO}_{\mathrm{x}}$ and soot formation. Other investigations obtained very good results from $12 \%$ until $8 \%$ of $\mathrm{XO}_{2}$. However, as it can be seen in the engine map (Figure 2), $8 \%$ of $\mathrm{XO}_{2}$ could not be set due to $\mathrm{A} / \mathrm{F}$ restriction or intake pressure limitations. Reaching $\mathrm{XO}_{2}$ of $8 \%$ would demand an intake air pressure of approximately 4.0 bar. Finally, $\mathrm{XO}_{2}$ higher than $12 \%$ would avoid LTC due to high combustion temperatures $[8,9,14,36,39,40]$. (e) In-cylinder air temperature range was defined firstly based on the range from $850 \mathrm{~K}$ and $1000 \mathrm{~K}$ investigated by Sandia National Laboratory. Good results were obtained using $T_{A M B}=800 \mathrm{~K}$, but in a realistic small engine with $r_{c}=15: 1$ such as the engine used in this work it would mean an intake air temperature around $0^{\circ} \mathrm{C}$. Also in the previous work by Benajes et al., with a $850 \mathrm{~K}\left(20^{\circ} \mathrm{C}\right) \mathrm{T}_{\mathrm{AMB}}$, wall impingement was imminent because the lift-off length for those points was longer than the physical limit (bowl radius) [19]. This range indicated an intake air temperature range (air+EGR) from $40^{\circ} \mathrm{C}\left(T_{A M B}=900 \mathrm{~K}\right)$ to $75^{\circ} \mathrm{C}\left(T_{A M B}=1000 \mathrm{~K}\right)$. Each intake air temperature requires a different engine map due to the fact that varying intake air temperature changes the relationship between $\rho_{\text {air }}$ and $p_{\text {int. }}$. Obs.: Ambient air temperature and in-cylinder air temperature are referred as the same parameter $T_{A M B}$. Nomenclature changes because the former refers to a constant volume vessel air temperature whereas the latter refers to an engine incylinder air temperature. (f) Furthermore, engine test plan range was set as it is presented in figure 2 (green triangle). The red dots on the area are the testing points. They are the intersection between air density and $\mathrm{XO}_{2}$ isolines and make it possible to read their respective values for intake air pressure and EGR rate which are the real controlled engine parameters.

In a small-bored diesel engine, the bowl diameter is very short. To evaluate wall impingement likelihood, for each point liquid length and lift-off length were calculated using equations (3) and (4) and compared to the distance from the injector tip to the piston bowl wall. The final test plan is exposed in the table 5.

Injection pressure (IP) values were fixed in 1200 bar, as in the previous study [19], and 1400 bar in order to observe the benefits of increasing injection pressure avoiding shortening injection duration significantly.

Two new nozzles were designed to reduce fuel injection rate around 25\%. The $6 \times 101 \mu \mathrm{m}$ configuration reduced only nozzle orifice diameter. The other one, $9 \times 083 \mu \mathrm{m}$, had the orifice diameter reduced while the number of orifices increased. Reducing fuel injection rate and orifice diameter simultaneously were supposed to enhance Diffusion-flame LTC conditions although using 9 orifices distance between sprays is shorter and jet-jet interaction is more likely to happen. 
Table 5. Engine test plan

\begin{tabular}{ll}
\hline Parameter & Value \\
\hline $\mathrm{mf}$ & $19 \mathrm{mg} / \mathrm{cc}$ \\
Engine Speed & $2250 \mathrm{rpm}$ \\
Engine Load & Around 9 bar IMEP (mid-load) \\
$\mathrm{IP}$ & $1200 \mathrm{bar}-1400 \mathrm{bar}$ \\
$\mathrm{SoE}$ & $-10 \mathrm{CAD}$ \\
$T_{\text {int }}\left(T_{A M B}\right)$ & $40^{\circ} \mathrm{C}(900 \mathrm{~K})-55^{\circ} \mathrm{C}(950 \mathrm{~K})-75^{\circ} \mathrm{C}(1000 \mathrm{~K})$ \\
$X O_{2}$ & $9 \%-10 \%-11 \%-12 \%$ \\
Air Density & $26 \mathrm{~kg} / \mathrm{m}^{3}-30 \mathrm{~kg} / \mathrm{m}^{3}-35 \mathrm{~kg} / \mathrm{m}^{3}-40 \mathrm{~kg} / \mathrm{m}^{3}$ \\
\hline
\end{tabular}

Oxygen concentration and air density were ranged as shown in figure 2, in a total of 10 points per intake air temperature. The total amount of test points in this parametric study was thirty so that for each engine tested point, only one engine operating parameter was varied. A predicted $\Phi_{H}$ calculation was performed based on equation (5) and the lowest predicted $\Phi_{H}$ average value was around 2.4 for $9 \mathrm{x} 083 \mu \mathrm{m}$ and 2.7 for $6 \mathrm{x} 101 \mu \mathrm{m}$, close to the proposed value that was around 2.0 to have all soot-precursors oxidized.[7,36,41]

\section{RESULTS AND ANALYSIS}

This section shows the obtained results from experimental engine test carried out ranging oxygen concentration, air density, intake air temperature, injection pressure and nozzle design. The influence of each parameter in terms of pollutant emissions and combustion characteristics are studied separately.

\subsection{AIR DENSITY}

Air density has no significant influence on equivalence ratio. However, increasing it tends to shorten lift-off length and reduce ignition delay. Based on this, it was expected to obtain similar NOx and Soot results among all tested $\rho_{\text {air. }}$. Increasing air density is a necessity in order to guarantee that the combustion process is mixing controlled. In figure 3, $\mathrm{NOx}$ and soot graphs compare different air densities using the same 9 x $83 \mu \mathrm{m}$ nozzle for $75^{\circ} \mathrm{C}$ intake air temperature for 1200 and 1400 bar injection pressure. All air densities had approximately the same values for the same oxygen concentration. Emissions of NOx are the same for both IP's, indicating that adiabatic flame temperatures are similar. Pickett stated that similar equivalence ratios at the lift-off length for different $\rho$ air do not precisely mean that soot formation and soot oxidation rates would be similar [14]. On the contrary, he observed that probably soot formation rate was affected. It means that, to have the same engine-out soot, oxidation rate might be affected at the same intensity than formation rate. It is not possible to know if soot formation and oxidation rates were affected. 

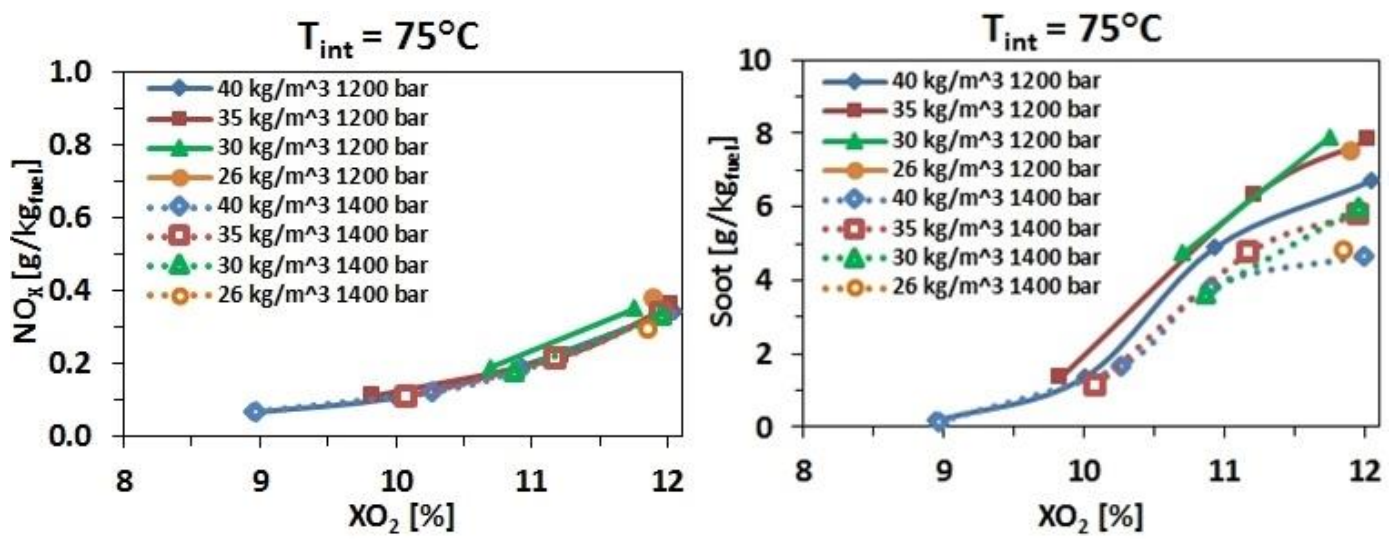

Figure 3 Air density comparison for $75^{\circ} \mathrm{C}$ using 9x083 $\mu \mathrm{m}$ nozzle for both injection pressures.

\subsection{AIR TEMPERATURE}

Reducing in-cylinder air temperature at TDC effectively reduced soot emissions. This temperature was controlled through intake air temperature. The gaps among different $T_{\text {int }}$ curves are decreased with the reduction in $X_{O 2}$ int until the point that there were no soot emissions. Figure 4 (a) and (b) present $T_{\text {int }}$ influence with $40 \mathrm{~kg} / \mathrm{m}^{3} \rho_{\text {air }}$ using $6 \times 101 \mu \mathrm{m}$ nozzle. There is a noticeable reduction when using $1400 I P$ but the curve trends are the same. For both $I P$ 's, there was a reduction in soot values for each $T_{\text {int. }}$. Also, differences among curves tend to disappear for the lowest oxygen concentrations. Soot emissions are very close to $0 \mathrm{FSN}$ with oxygen concentrations around $10 \%$ and extinguish at $9 \%$. Under lower $X_{O 2}$ int there is no evidence of $T_{\text {int }}$ influence on combustion process, and consequently, soot formation.

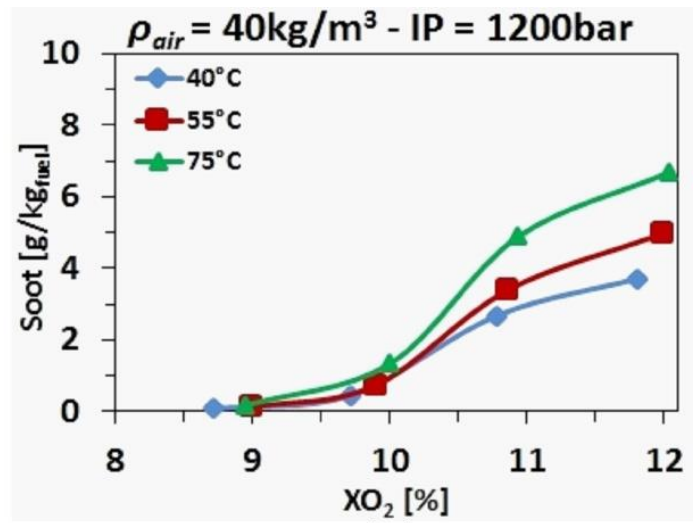

(a)

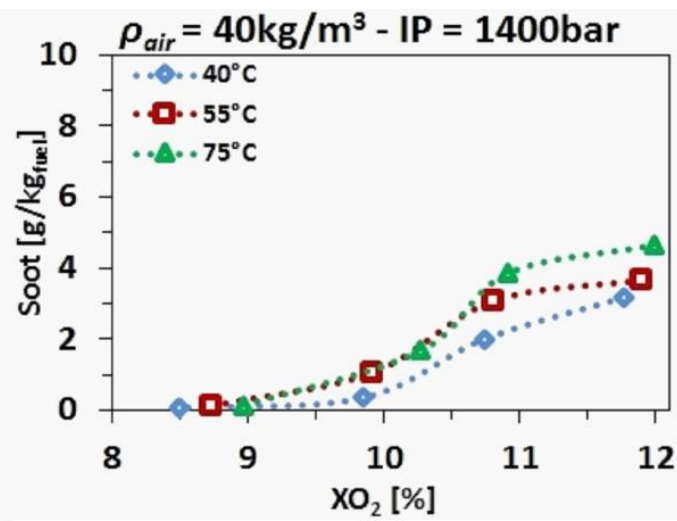

(b)

Figure 4 Intake air temperature influence with $40 \mathrm{~kg} / \mathrm{m}^{3}$ using $9 \mathrm{x} 083 \mu \mathrm{m}$ and $6 \mathrm{x} 101 \mu \mathrm{m}$ nozzle for both injection pressures

Figure 5 shows maximum adiabatic flame temperature $\left(T_{A d_{\_}} \operatorname{Max}\right)$ using the same configuration from Figure $4(\mathrm{~b})$. In the graph, $T_{A d \_}$Max is directly related to intake air temperature. The lower intake air temperature the more reduced are engine-out soot emissions. 


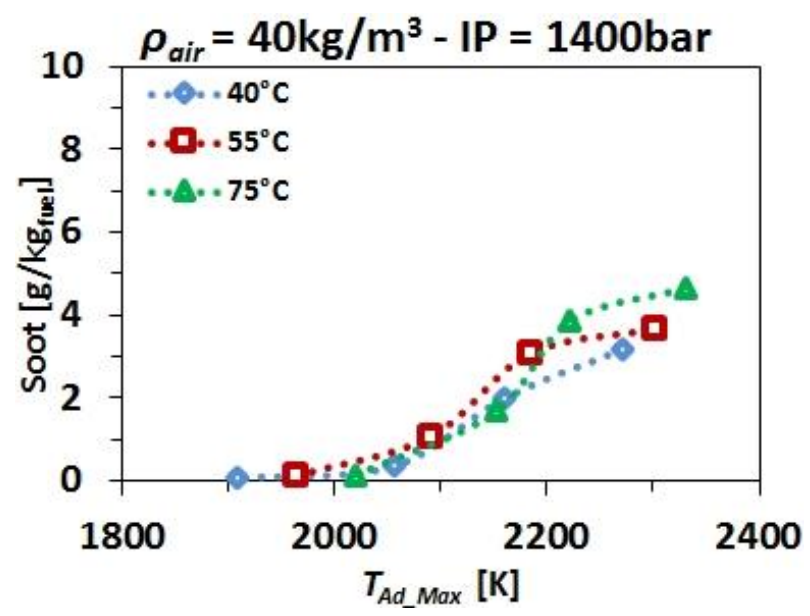

Figure 5 Maximum adiabatic flame temperature using 9x083 $\mu \mathrm{m}$ nozzle

Soot emissions are intimately connected to soot formation and soot oxidation rates which depend directly on adiabatic flame temperature. Moreover, equivalence ratio at lift-off length $\left(\mathscr{\emptyset}_{H}\right)$, is one of the main factors that controls soot precursor formation before the flame and effectively avoids soot formation. Remembering, $\varnothing_{H}$ is reduced by the decrease in $T_{i n t}$ due to the lengthening of $H$. Figure 6 presents soot emissions vs $\varnothing_{H}$ graph. $\varnothing_{H}$ values presented in the graph were calculated using equation (5) shown previously in section 3.3. Grey arrow indicates oxygen concentration reduction. Straight lines connect results for $1200 \mathrm{bar} I P$ and dotted lines for 1400 bar IP. For the highest $\mathrm{O}_{2}$ concentration, line slopes are different. while reducing $\mathrm{XO}_{2} \%$ line slopes tend to equalize for both $I P$. For $9 \%$, soot emissions are insignificant.

Comparing lines with the same $T_{\text {int }}$ and different $I P$ 's, in general, there is a reduction in soot emissions that is attributed to the increased $I P$ since it causes a reduction on $\emptyset_{H}$. Comparing lines with the same $I P$ for distinct $T_{\text {int }}$, soot emission reduction is even more intense. It happened because decreasing $T_{\text {int }}$ tends to reduce Adiabatic Flame Temperature $\left(T_{A D}\right)$ and $\varnothing_{H}$ simultaneously. It is not possible to distinguish the soot reduction fraction due to the enhancement of $\emptyset_{H}$ or reduction of $T_{A D}$ despite of the fact it is known both factors have substantial influence on this phenomenon.

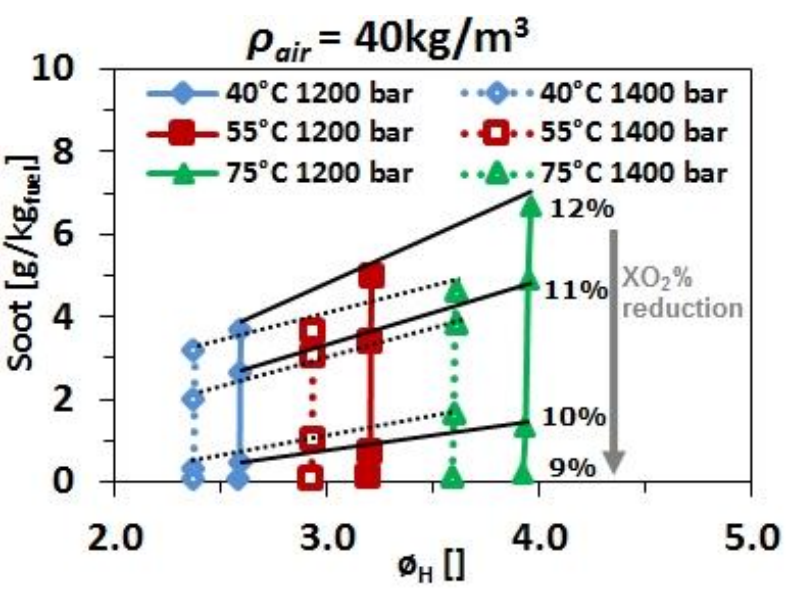

Figure 6 Soot vs $\emptyset_{H}$ using 9x083 $\mu \mathrm{m}$ nozzle

Combustion noise and $\mathrm{CO}, \mathrm{HC}$ emissions felt the effect of $T_{\text {int }}$ reduction. Figure 7 shows combustion noise vs Ignition delay graph using $9 \times 083 \mu \mathrm{m}$ and 1200 bar IP. The black lines indicate the results with the same oxygen concentration. Comparing the $3 T_{\text {int }}$, combustion noise increases around $1 \mathrm{dBa}$ with its increasing. $T_{\text {int }}$ is one of 
the parameters that controls unburned gas temperature before combustion ignition. Unburned gas temperature is related to ignition delay and its reduction tends to increase it. For similar conditions (constant $\rho_{a i r}, I P$ and $X O_{2}$ ), increasing ignition delay cause higher combustion noise because the amount of fuel available to be burnt during premixed combustion is increased. It was observed that variation of pressure rise rate caused by intake temperature was not significant to explain this reduction in combustion noise, being the ignition delay the most relevant parameter. However, combustion noise levels are very low in all the studied cases if compared to an ordinary HSDI, mainly due to high EGR rates used in this investigation.

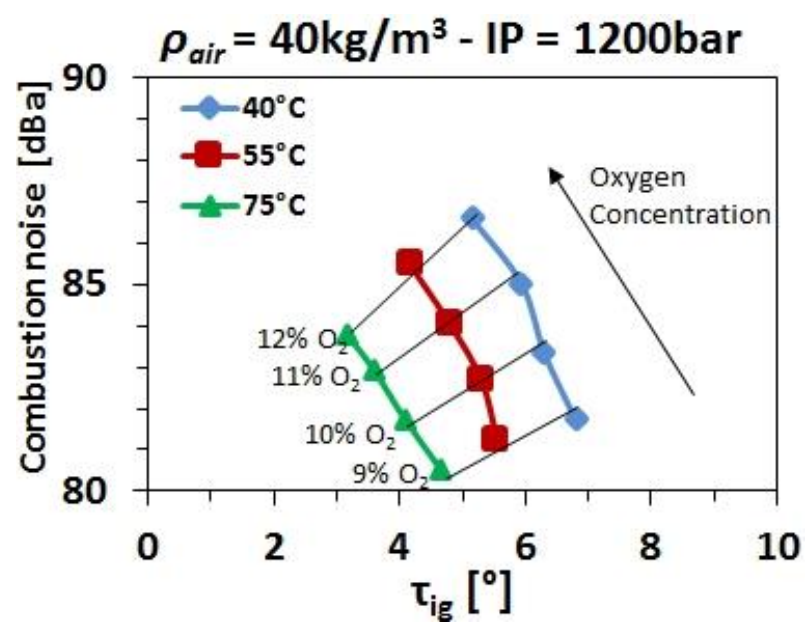

Figure 7 Combustion noise vs Ignition Delay for 9x083 $\mu \mathrm{m}$ nozzle

\section{3. $\mathrm{O}_{2}$ CONCENTRATION}

Oxygen concentration was reduced from $12 \%$ to $9 \%$. Reducing $\mathrm{XO}_{2}$ also reduces $T_{A D}$ with no penalty to $\emptyset_{H}$. In figure 8, it is presented RoHR (Rate of Heat Release) curves for $\rho_{\text {air }}$ of $40 \mathrm{~kg} / \mathrm{m}^{3}$ and $T_{\text {int }}$ of $40^{\circ} \mathrm{C}$ for the 3 tested nozzles. Dotted lines over the graphs determine injection rate for each nozzle with its respective $I P$. Analyzing these graphs, it is possible to observe the effects of $\mathrm{XO}_{2}$ reduction on combustion process. 


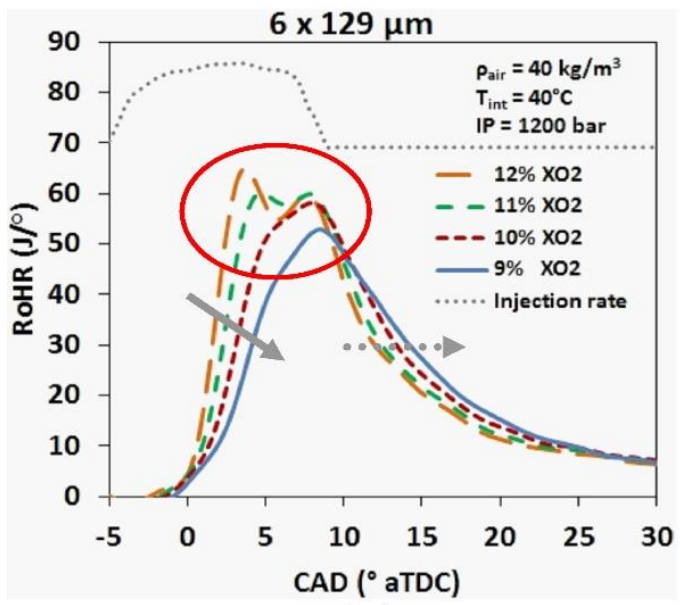

(a)

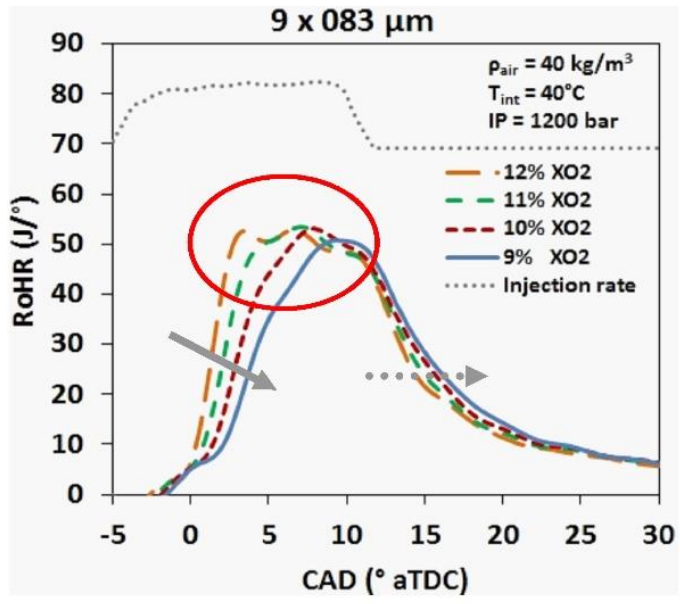

(c)

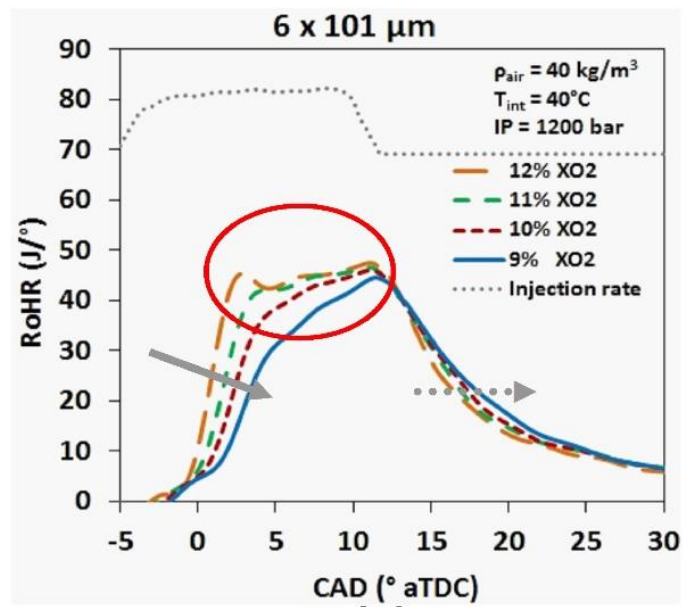

(e)

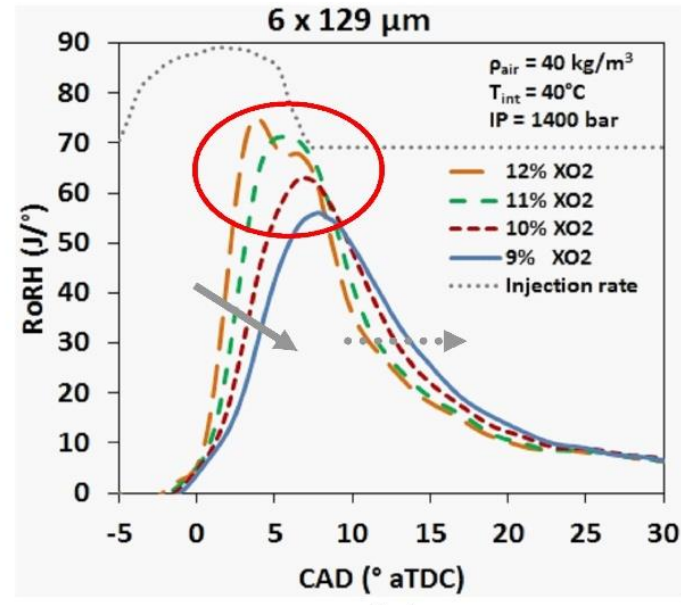

(b)

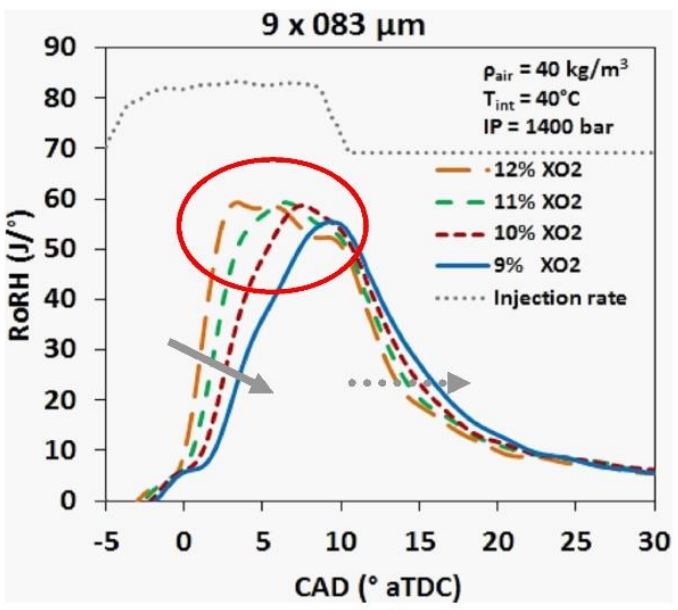

(d)

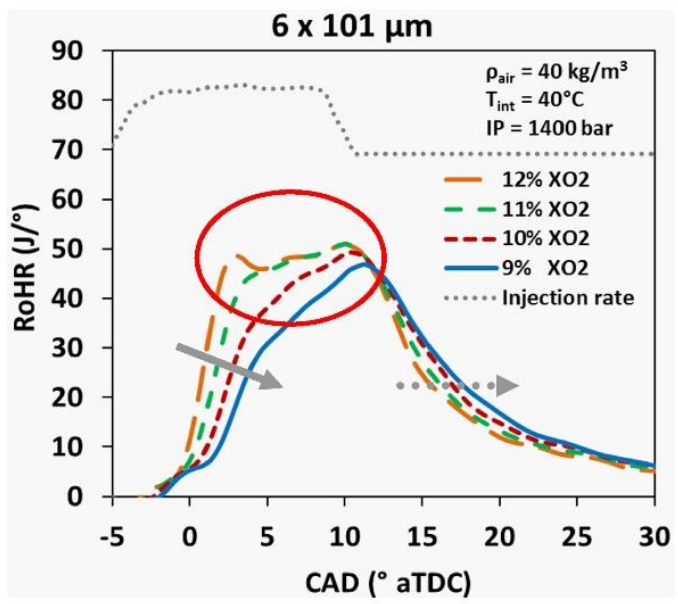

(f)

Figure 8 RoHR for the three nozzles

First of all, premix combustion slope reduces due the reduction of reaction speed (grey arrows). Second, premix combustion peak is reduced and moves towards mixing controlled combustion (red circles). Also, slowing combustion process causes a higher of heat release rate at the end of the combustion process, when combustion is decelerating, after the end of injection (dotted arrows). At last, other phenomena that can be observed were the increase of ignition delay and presence of cold flame reactions, also observed by Bruneaux in his studies on LTC 
$[15,17]$. Those observations occurred for all studied cases of this investigation, independently of injection rate, nozzle diameter and injection pressure.

Figure 9 presents $T_{A D}$ curves in relation to oxygen concentration. Test set-up was similar to the exposed in previous figure, with $6 \times 101 \mu \mathrm{m}$ nozzle and $1200 \mathrm{bar} I P$. As a consequence of EGR increase, $T_{A D}$ gradually decreased. This reduction in adiabatic flame temperature is very significant and important to avoid thermal $N O_{X}$ mechanism and soot formation simultaneously.

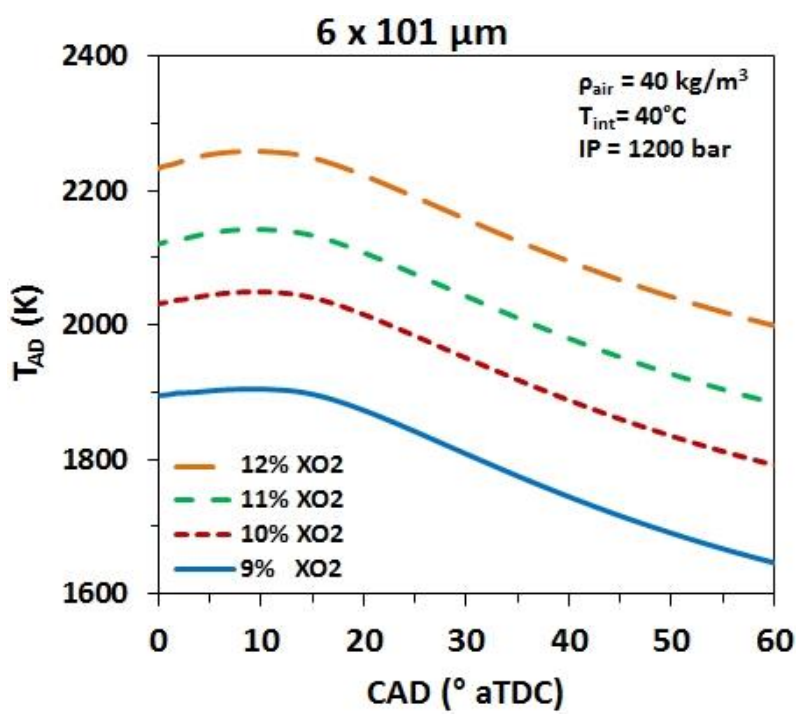

Figure 9 Adiabatic flame temperature for 6 x $101 \mu \mathrm{m}$ nozzle and $1200 \mathrm{bar}$ IP

In figure 10, it is possible to find $\mathrm{NO}, \mathrm{HC}, \mathrm{CO}$, combustion noise and IMEP. Test conditions were $40^{\circ} \mathrm{C}$ and 40 $\mathrm{kg} / \mathrm{m}^{3}$ for $T_{\text {int }}$ and $\rho_{\text {air }}$, respectively. The observed trends are very similar, independent of nozzle. NOx graph shows a significant reduction with $\mathrm{XO}_{2}$ reduction. The decrease in $T_{A D}$ inhibits thermal NOx production, reaching very low level with $9 \% \mathrm{O}_{2}$. Undoubtedly, $\mathrm{XO}_{2}$ range for this study was very low and, although the NOx reduction was really intensive, their values are insignificant. 

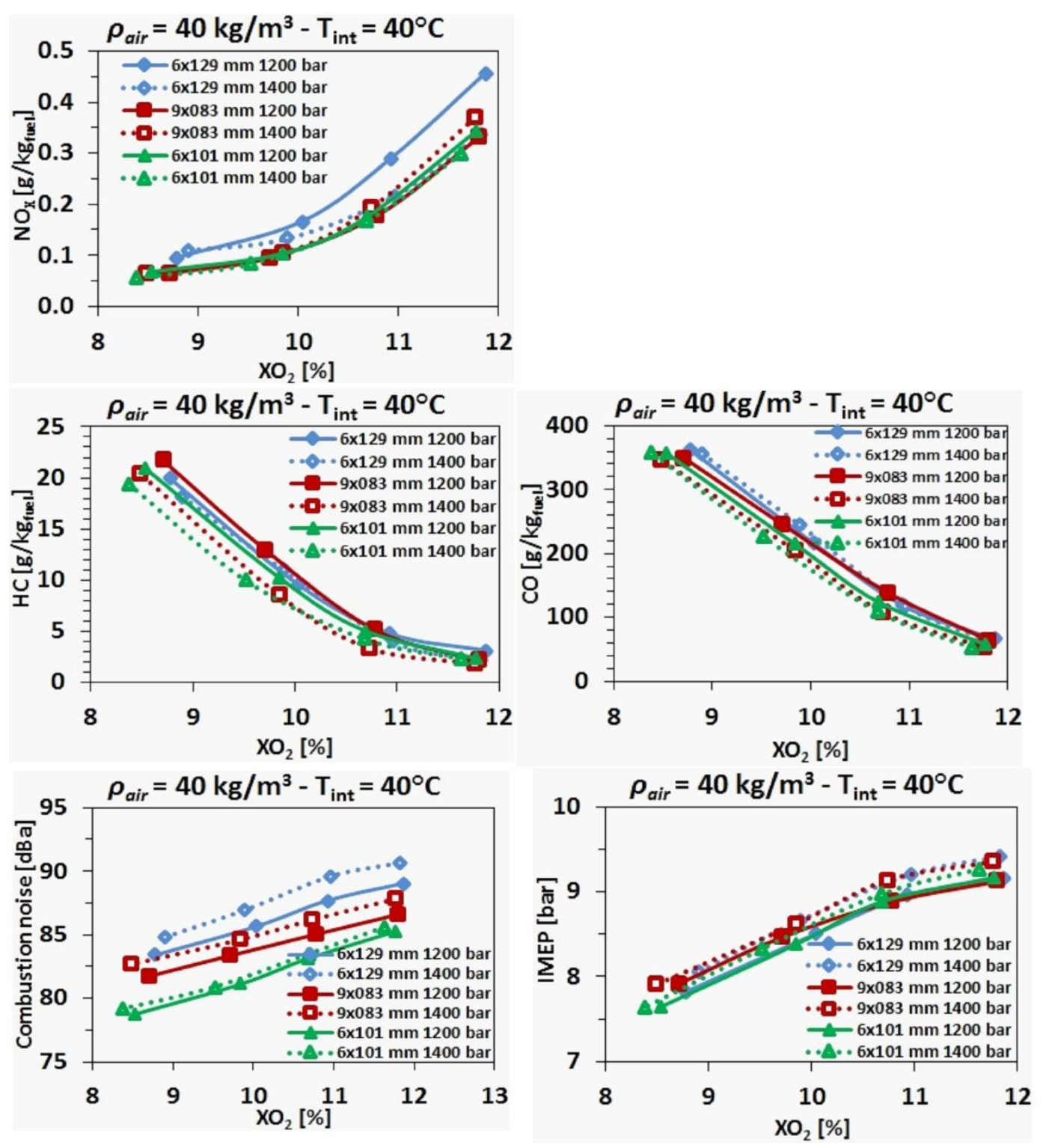

Figure $10 \mathrm{NO}, \mathrm{HC}, \mathrm{CO}$, combustion noise and IMEP vs $\mathrm{XO}_{2}$

Soot emissions reduce by decreasing oxygen concentration (Figure 11 ). Also, with $9 \% \mathrm{XO}_{2}$, soot emissions were practically zero. The very low $T_{A D}$ affected soot formation so intensely that no soot was formed in those tests. Concerning to $\mathrm{HC}$ and $\mathrm{CO}$, comments are very similar. Despite the fact that reducing $\mathrm{XO}_{2}$ causes great benefits to $\mathrm{NOx}$ and soot formation, $\mathrm{HC}$ and $\mathrm{CO}$ were affected negatively and reached unacceptable values. The reason can be observed in RoHR curves (figure 8). The reduction in $\mathrm{XO}_{2}$ and its consequent combustion process reaction deceleration cause a deterioration of the process. This can also be confirmed by IMEP graph. At last, combustion noise decreased around $5 \mathrm{dBa}$, from $12 \%$ to $9 \% \mathrm{XO}_{2}$. Combustion noise is intimately related to reaction velocity during premixed combustion. In figure 8 , it is seen that premixed combustion changed its trend and it affected positively combustion noise, producing a smoother combustion if compared to the points with higher $\mathrm{O}_{2}$ concentrations. Also there is an increase in ignition delay when oxygen concentration is reduced (Figure 7), that might have contributed to a combustion noise rise.

\subsection{INJECTION PRESSURE}

Increasing injection pressure increases lift-off length and more air can be absorbed upstream it, enhancing mixing process and, consequently, reducing soot precursor formation. However, it increases injection rate and shortens 
injection duration that, in some cases, could make it more difficult to reach mixing controlled combustion and flame stabilization.

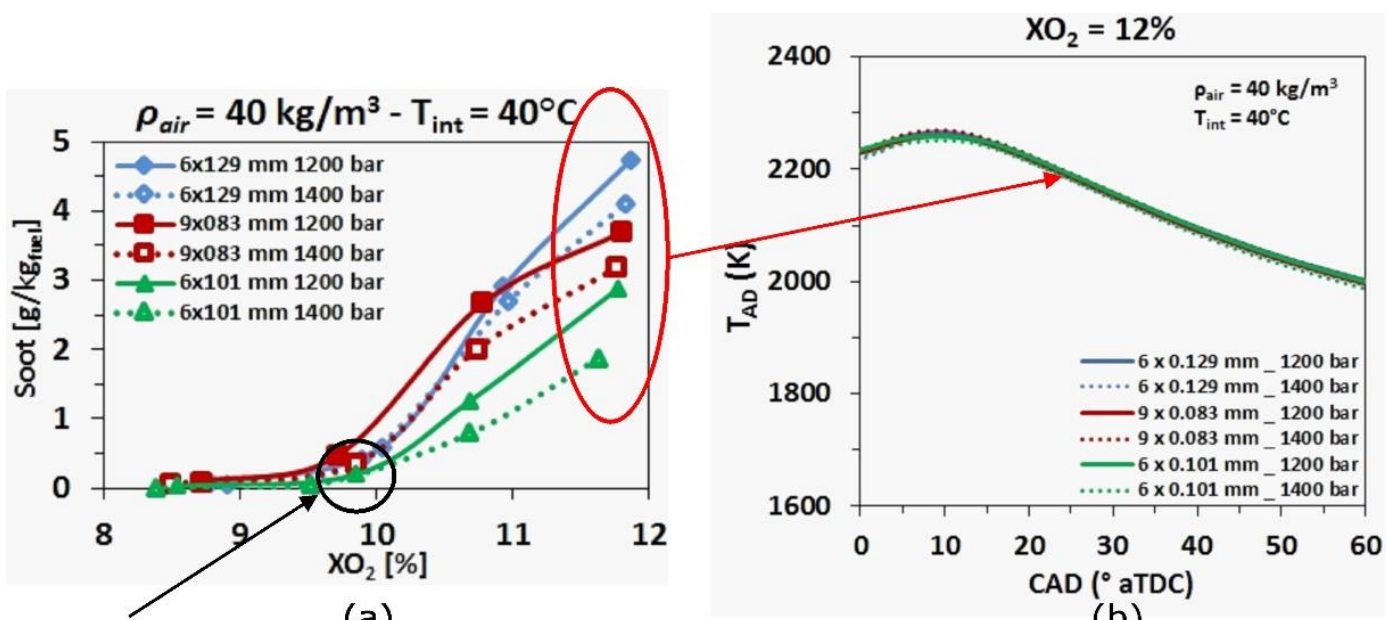

(a)

(b)

Figure 11 (a) Soot vs $\mathrm{XO}_{2}$ with $\rho_{\text {air }}$ and $T_{\text {int }}$ of $40 \mathrm{~kg} / \mathrm{m}^{3}$ and $40^{\circ} \mathrm{C}$, respectively and (b) $T_{A D}$ for $12 \% \mathrm{XO}_{2}$.

In Figure 11, it is shown the Soot vs $\mathrm{XO}_{2}$ graph (a) and Adiabatic flame temperature for $12 \%$ of oxygen concentration (b). In the graph (a), there is a soot emission reduction when IP is increased from 1200 bar to 1400 bar, mainly for higher oxygen concentrations, due to the reduction of equivalence ratio at the lift-off length cause by IP increment. For the same oxygen concentration $\left(\mathrm{XO}_{2}=12 \%\right)$, adiabatic flame temperature is constant, independently of $I P$ or nozzle (red circle) (Figure 11(b)). As it was seen, reducing $\mathrm{XO}_{2}$ causes soot formation extinction due to $T_{A D}$ reduction effect. It would cancel any effect of $I P$ on soot formation.

Results for $\mathrm{NOx}, \mathrm{HC}, \mathrm{CO}$, combustion noise and IMEP are presented on the graphs of Figure 10. The enhancement of mixing capability caused by IP increment helps reducing $\mathrm{HC}$ and $\mathrm{CO}$ emissions. The behavior is similar for the 3 nozzles. However, the new nozzles with reduced injection rates were more effective than $6 \mathrm{x}$ $129 \mu \mathrm{m}$ nozzle. The enhancement is also observed in IMEP result graph that presents a 5\% increase in all $\mathrm{XO}_{2}$ range. Nonetheless, NOx emissions are not affected once injection pressure have any influence on $T_{A D}$. Emissions and IMEP had a noticeable improvement, but combustion noise increased slightly. The increased fuel mass injected in the cylinder before the combustion ignition associated to the better mixing capability contributed to a faster and more violent premixed combustion, and consequently, more noise.

\subsection{INJECTOR NOZZLE}

In this investigation, the new nozzle development aimed to enlarge the duration and improve diffusive combustion process through which it would be easier to obtain Diffusion-flame LTC. Both nozzles were designed in order to: (1) Reduce fuel injection rate; (2) Reduce orifice diameter and (3) Keep or increase number of orifices with no loss by jet-jet interaction.

Figure 11 shows a comparison among the 3 nozzle with $T_{\text {int }}$ and $\rho_{\text {air }}$ of $40^{\circ}$ and $40 \mathrm{~kg} / \mathrm{m}^{3}$, respectively, for both IP's (1200 bar and 1400 bar). Soot emissions are not inversely proportional to orifice diameter reduction, as suggested previously [38]. Despite of the fact that 9x083 $\mu \mathrm{m}$ nozzle equivalence ratio was the smallest among the 3 nozzles, its soot emissions was not the lowest. Equivalence ratio equation (eq. 5) is valid for controlled thermodynamic condition environment in a constant volume vessel, indicating that they are just an approximation for the development and may be used more qualitatively than quantitatively when comparing the nozzles. The higher soot formation of 9x083 $\mu \mathrm{m}$ probably was caused by an undesirable jet-jet interaction, which causes liftoff length shortening and, proportionally, reduces the amount of entrained air downstream lift-off length, as observed by Musculus [16] and Garcia [21]. 

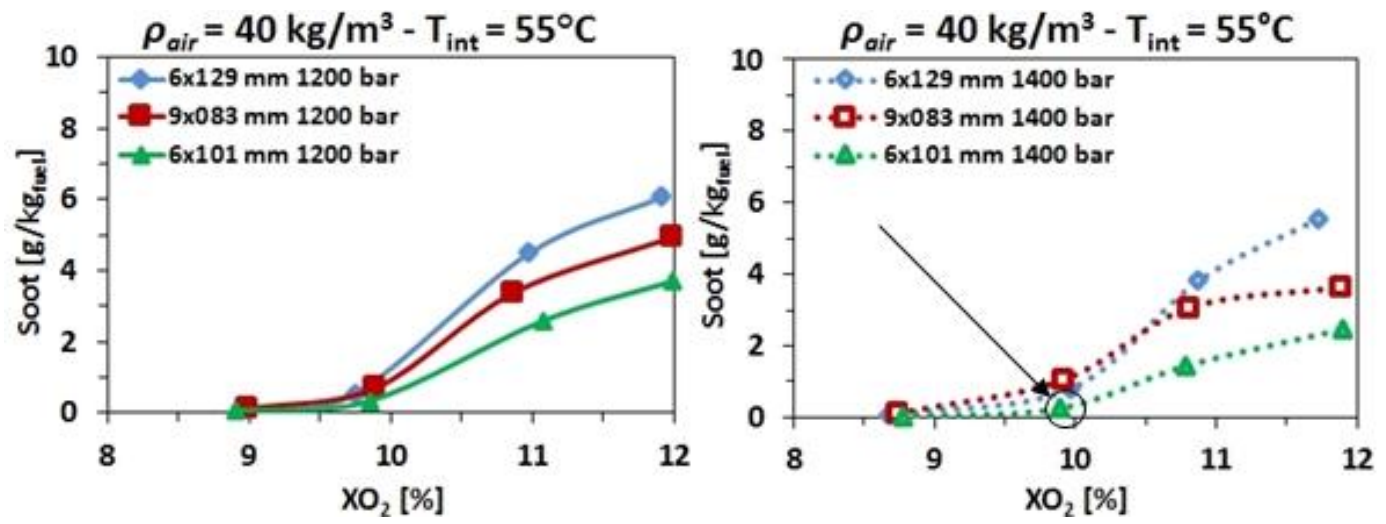

Figure 12 Soot vs $\mathrm{XO}_{2}$ for $\rho_{\text {air }}$ and $T_{\text {int }}$ of $40 \mathrm{~kg} / \mathrm{m}^{3}$ and $55^{\circ} \mathrm{C}$, respectively.

In figure 12 , soot emissions are presented for each $I P$ separately, this time with $55^{\circ} \mathrm{C} T_{\text {int }}$. The behavior is very similar if compared to the figure 11 results where $6 \times 101 \mu \mathrm{m}$ nozzle presented the lowest emissions. On the right graph, set to 1400 bar $I P$, soot extinction occurred even with $10 \%$ oxygen concentration when using $6 \times 101 \mu \mathrm{m}$ nozzle (black arrow). This is very important once associating 6x101 $\mu \mathrm{m}$ nozzle with 1400 bar $I P$, besides bringing benefits respect to soot, also helps to improve other parameter results, such as $\mathrm{HC}$ and $\mathrm{CO}$, as will be shown later.

The graphs of $\mathrm{HC}, \mathrm{CO}$ and $\mathrm{NO}$ x emissions in figure 10 compares the behavior of the 3 nozzles. For HC emissions, all nozzles seem to have similar behavior and values. They seem to be affected by the injection pressure, following this pattern: For 1200 bar IP, 6x101 $\mu$ mozzle have better results than 6x129 $\mu \mathrm{m}$ nozzle while 9x083 $\mu \mathrm{m}$ nozzle presents insignificant differences from the conventional 6x129 $\mu \mathrm{m}$ nozzle. With a IP of 1400 bar, both nozzles present better results than the conventional nozzle even though $6 \times 101 \mu \mathrm{m}$ nozzle is still slightly better than 9x083 $\mu \mathrm{m}$ nozzle.

The effect of the nozzles on $\mathrm{CO}$ emissions is very alike to $\mathrm{HC}$. The nozzle 9x083 $\mu \mathrm{m}$ does not present the best result though it has the smallest orifice diameter. Besides, NOx emissions do not seem to be sensitive to the nozzle characteristics probably because adiabatic flame temperature is more dependent from oxygen concentration than to the characteristics of the spray.

Jet-jet interaction in 9x083 $\mu \mathrm{m}$ nozzle, caused by the increased proximity between two adjacent sprays, might be the reason of combustion process worsening. However, increasing injection pressure slightly reduces $\mathrm{CO}$ and $\mathrm{HC}$ to levels near to $6 \mathrm{x} 101 \mu \mathrm{m}$ nozzle. In spite of this little enhancement, soot emission was not significantly affected to be compared to $6 \times 101 \mu \mathrm{m}$ nozzle results.

For the 3 nozzles, IMEP are very similar, such as $\mathrm{CO}$ and $\mathrm{HC}$, and cannot be considered a factor that fells intensively nozzles characteristics although $6 \times 101 \mu \mathrm{m}$ nozzle presents little loss comparing to the others.

Moreover, injection rate seems to have an important influence over combustion noise. If it is higher, the amount of fuel injected prior to combustion ignition is higher, heat release is more intense due to more energy available. Reducing injection rate cause exactly the opposite effect and combustion noise tend to be reduced. It can be seen on the combustion noise graph in figure 10, where noise curves follow exactly injection rate order (Figure 13).

Figure 13 presents 2 comparisons among RoHR of all nozzles with both injection pressures. In all the cases, Diffusion-flame LTC was achieved. As it was expected, Diffusion-flame LTC phenomenological concept with no soot and $\mathrm{NOx}$ formation simultaneously reveals a smooth heat release rate. There is no premixed combustion peak and it is noticeable a small cold flame reaction area. Diffusion-flame combustion is more evident, mainly using the new nozzles especially designed to reduce injection rate. In spite of being designed to have the same injection rate (hydraulic injection rate at 100 bar are very similar), with 1200 bar or 1400 bar it is possible to notice a significant difference, around 4\%. Furthermore, in the cases which NOx and soot were despicable, combustion process confirmed to be diffusive indeed. 

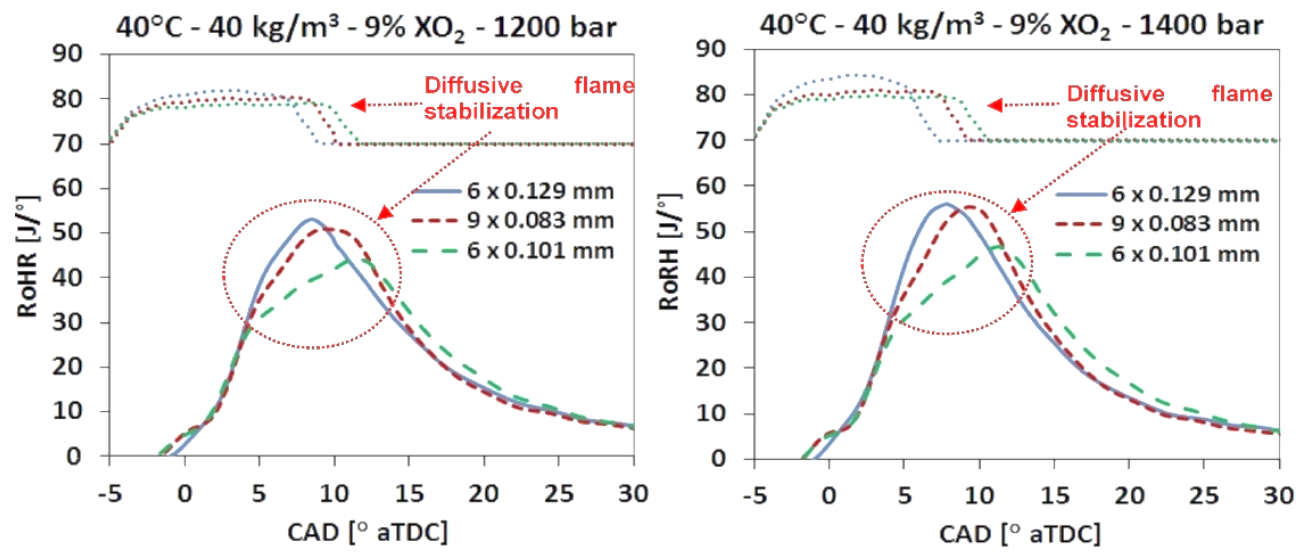

Figure 13 RoHR for 3 tested points of Diffusion-flame LTC with 1200 bar (top) and 1400 bar (below) IP.

\subsection{JET-WALL INTERACTION}

Some solutions proposed in this investigation to improve Diffusion-flame LTC can increase the likeliness of a jet-wall interaction. However, reducing orifice diameter tends to avoid it. Jet-Wall interaction, if occurred, may have affected some results and, in order to try to reduce its effect in a future work, it was investigated.
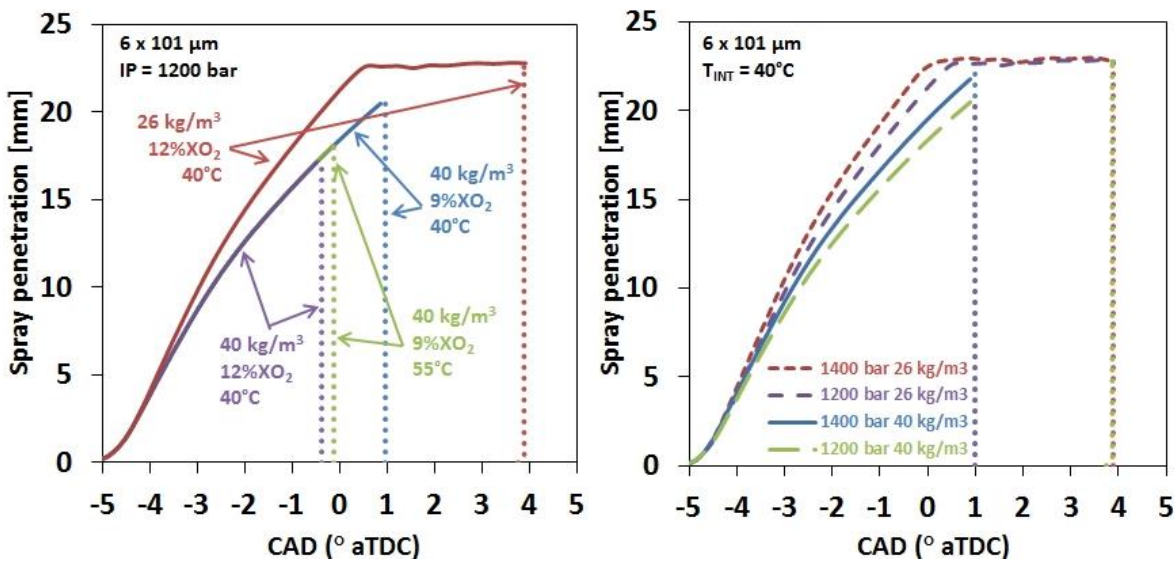

Figure 14 Spray penetration in the cylinder bowl for different configuration using 6x101 $\mu$ m nozzle.

In this combustion concept, spray penetration does not vary with oxygen concentration and TDC unburned gas temperature but both parameters have a significant effect on ignition delay. In the non-reactive spray simulation using 6x101 $\mu \mathrm{m}$ nozzle, shown in figure 14, vertical dotted lines indicate start of combustion (SoC). Spray penetration, represented by the continuous line, is interrupted at SoC because spray model is non-reactive.

In the left graph, spray penetration and ignition delay for $26 \mathrm{~kg} / \mathrm{m}^{3}$ are much longer than for $40 \mathrm{~kg} / \mathrm{m}^{3} \rho_{\text {air }}$, indicating that higher air densities help reduce the probability of wall-impingement. Also, reducing $T_{\text {int }}$ to $40^{\circ} \mathrm{C}$ and $\mathrm{XO}_{2}$ from $12 \%$ to $9 \%$ makes ignition delay longer. Nonetheless, $\rho_{\text {air }}$ has more influence on ignition delay than $\mathrm{XO}_{2}$ or $T_{\text {int }}$, or both simultaneously, in the range of this study, as had been stated by Picket et al [37] through equation (6). At the LTC configuration ( $\rho_{\text {air }}=40 \mathrm{~kg} / \mathrm{m}^{3}, T_{\text {int }}=40^{\circ} \mathrm{C}$ and $X O_{2}=9 \%$ ), ignition delay is increased very dangerously until almost reach the time needed to have wall impingement, as it is possible to observe. Since ignition does not occur instantly, it is coherent to consider that wall impingement may have happened.

In the right graph, penetration increases with injection pressure because increasing $I P$ leads to a higher injection velocity. However, ignition delay was not affected by $I P$ as can be seen in figure 15 which compares ignition delay for various $\mathrm{XO}_{2}, \rho_{\text {air }}$ and $I P$. Based on this graph, oxygen concentration affects ignition delay but with a lower intensity than air density. Maybe, due to fact that air density is extremely high and oxygen concentration too low, IP influence on ignition delay was cancelled in this range of operation. In other words, the fact that $I P$ 
increases penetration with no change in ignition delay indicates that the risk of wall impingement is higher comparing to 1200 bar.

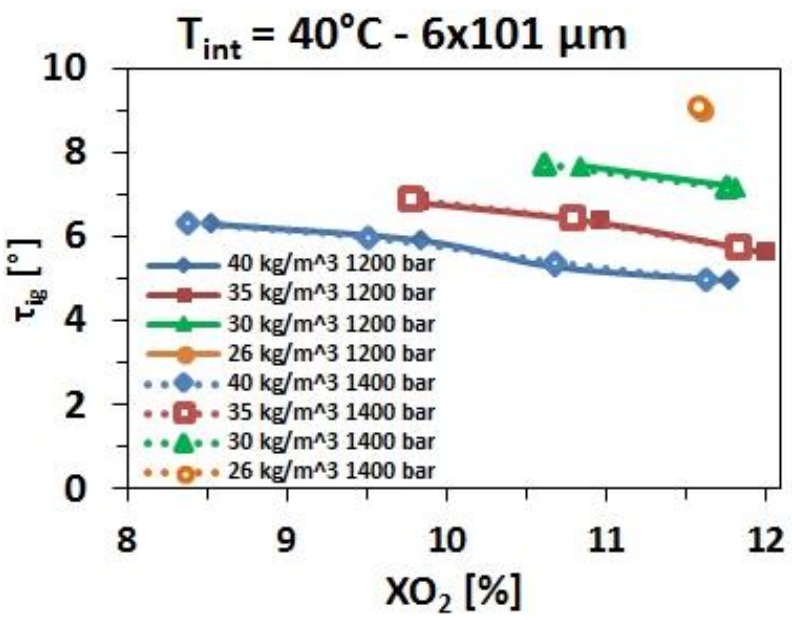

Figure 15 Ignition delay for various $\rho_{\text {air }}$ and IP

Figure 16 presents $\mathrm{HC}$ emissions using $6 \times 101 \mu \mathrm{m}$ nozzle. Left graph contrasts it against $\rho_{\text {air }}$ and $I P$ and the right one against intake air temperature and injection pressure. Concerning to $\mathrm{XO}_{2}, \mathrm{HC}$ emission rise gradient is remarkably higher for lower concentrations. Contrasting this information with figure 14 graphs, it is possible to observe that wall impingement likely occurred. Since $\mathrm{XO}_{2}$ also causes combustion process deterioration, it is difficult to quantify the influence of each effect on $\mathrm{HC}$. With $26 \mathrm{~kg} / \mathrm{m}^{3}$, $\mathrm{HC}$ emissions increased if compared to the other densities what could mean wall impingement once oxygen concentration and intake air temperatures are the same. The same behavior is observed when comparing different $T_{\text {int }}$ 's: decreasing it leads to an increase in ignition delay and possibly increase wall impingement or the amount of fuel that impinges. For injection pressure, although penetration graphs indicated wall impingement was prone to occur and $\mathrm{HC}$ would increase, these pollutant emissions decreased which means mixing process enhancement influence on $\mathrm{HC}$ was stronger than the possible wall impingement's.
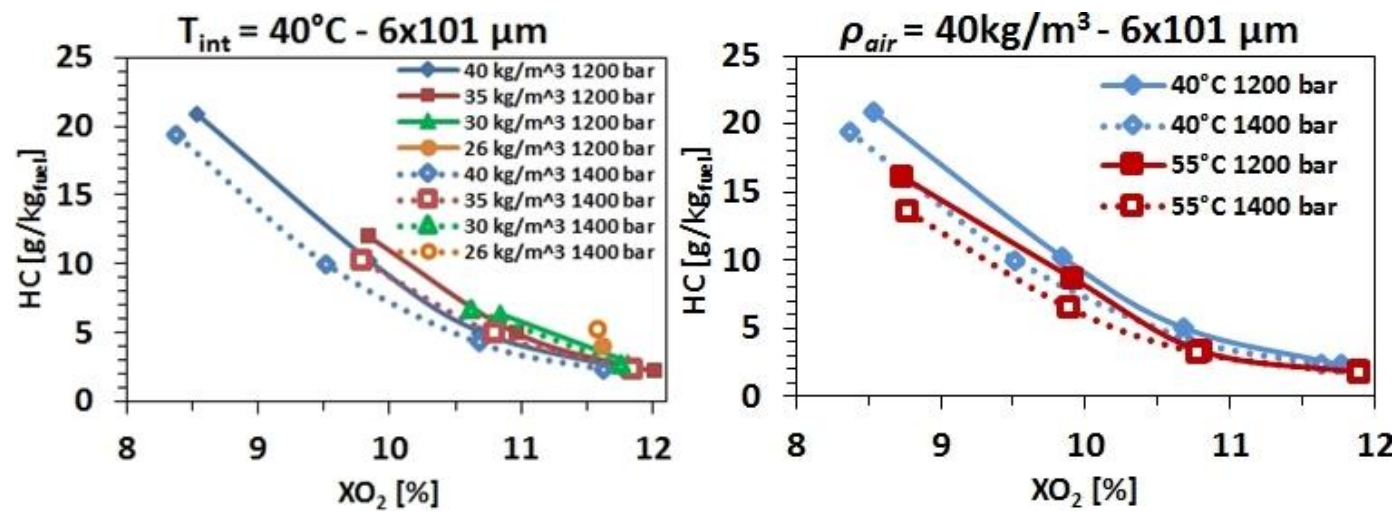

Figure $16 \mathrm{HC}$ emissions using $6 \times 101 \mu \mathrm{m}$ nozzle.

\subsection{DISCUSSION}

Based on the results, an analysis is carried out on the new proposals to enhance Diffusion-flame LTC concept. In figure 11 (a) and figure 12, there are 2 points pointed out with a black arrow. They had similar configurations, with $40 \mathrm{~kg} / \mathrm{m}^{3}$ air density and 1400 bar injection pressure, using the same nozzle, 6 x $101 \mu \mathrm{m}$, differing only by $T_{\text {int }}, 40^{\circ} \mathrm{C}$ (figure 11 ) and $55^{\circ} \mathrm{C}$ (figure 12). For both points, soot emissions were despicable although oxygen configuration was $10 \%$. It was really remarkable that clean combustion concept, with no soot and $\mathrm{NO}$ x formation, was achieved with an oxygen concentration $1 \%$ higher than the original configuration. It means that Diffusion- 
flame LTC was achieve with a EGR rate reduced from $70 \%$ (with $40^{\circ} \mathrm{C}$ ) to $67 \%\left(55^{\circ} \mathrm{C}\right)$ [19]. The development of the new $6 \times 101 \mu \mathrm{m}$ nozzle, with micro-orifices, associated to a higher injection pressure and a reduced unburned gas temperature, enhanced conditions to achieve an improved Diffusion-flame LTC.

Once Diffusion-flame LTC concept had been achieved, other factors such as $\mathrm{HC}$ and $\mathrm{CO}$ emissions, IMEP and combustion noise were examined. Figure 17 shows a comparison between $9 \%$ and $10 \% \mathrm{XO}_{2}$ using $6 \times 101 \mu \mathrm{m}$ nozzle. Circles point out results with the same $\mathrm{XO}_{2}$ values. $\mathrm{HC}$ and $\mathrm{CO}$ emissions obtained a $50 \%$ result comparing to $9 \%$ oxygen. Also, IMEP increased around 0.5 bar, which means approximately a $7 \%$ increase in engine performance. Considering that $\mathrm{FC}$ was constant, it means a similar improvement in specific fuel consumption. Combustion noise increased from around $79-80 \mathrm{dBa}\left(9 \% \mathrm{XO}_{2}\right)$ to $81-82 \mathrm{dBa}\left(10 \% \mathrm{XO}_{2}\right)$. Although it increased, combustion noise remained in a very low level, still under the best values obtained using the conventional nozzle. Based on this, developing a nozzle with reduced nozzle orifice diameter and reduced hydraulic mass flow aiming the extension of Diffusion-flame LTC range really led to very significant results.

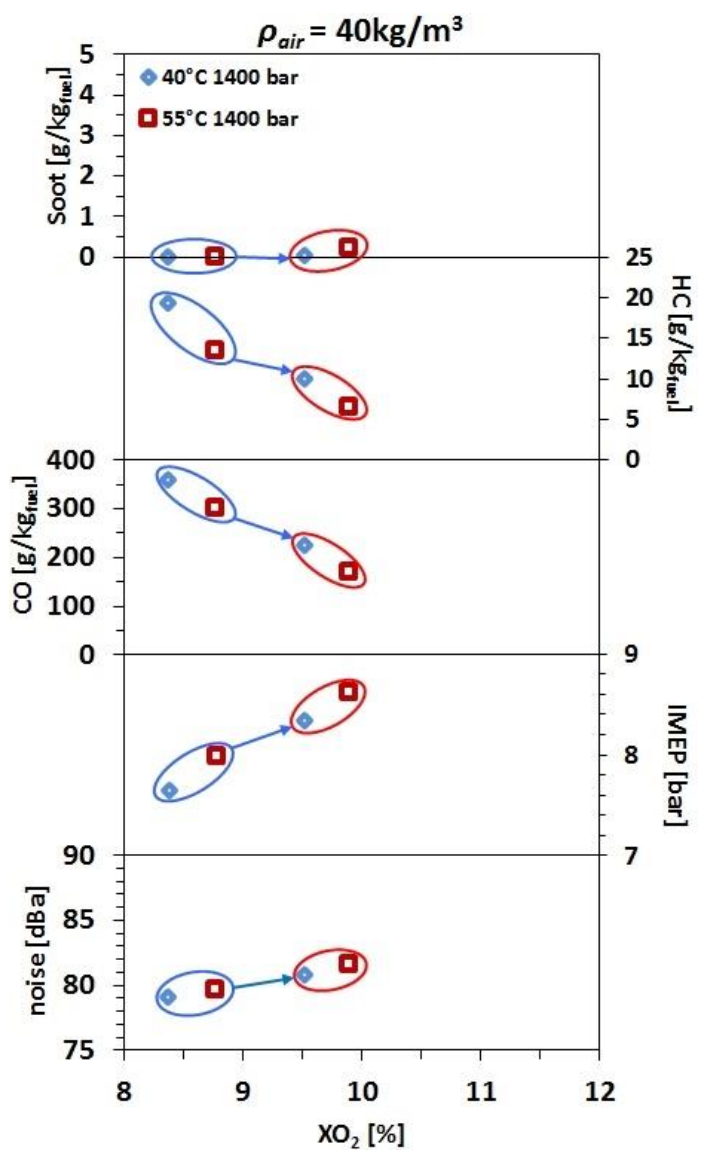

Figure 17 Comparison between $9 \%$ and $10 \% \mathrm{XO}_{2}$ in order to evaluate combustion noise, IMEP, $\mathrm{HC}$ and $\mathrm{CO}$ emission improvement.

Diffusive LTC was tested only at mid load and mid speed with the purpose to prove its feasibility. It needs to be tested in other conditions to go to a production engine. Some consideration must be done for other operational conditions. For low loads, achieving Diffusive LTC might not be possible due too very short injection duration. In this case, other type of premixed combustion would be more suitable.

On the contrary, Diffusive LTC was achieved using a micro-hole nozzle and increased injection pressures. For high loads, it might be tested with higher injection pressures, in order to avoid very long fuel injections. One solution might be an injection system with variable pressure to fulfill all load requirements. Moreover, this 
concept demands a very high intake pressure in order to ensure the appropriate air density. Thus, the turbocharging system must be rethought in order to achieve very high pressures on mid-loads and high-load.

\section{CONCLUSIONS}

An experimental study on the improvement of Diffusion-flame LTC concept obtained by Benajes et al. [19] aiming to extend its range was carried out. The conclusions are pointed out below:

It was possible to extend Diffusion-flame LTC range avoiding NOx and soot formation simultaneously, using the new $6 \times 101 \mu \mathrm{m}$ nozzle associated to the increased injection pressure. The proposed modifications made possible to reach this combustion mode with $10 \%$ oxygen concentration and an intake air temperature of $55^{\circ} \mathrm{C}$, which enhanced significantly $\mathrm{CO}, \mathrm{HC}$, IMEP if compared to the previous results obtained by Benajes et al.

Air density does not affect soot emissions but allows very low oxygen concentration, essential for Diffusionflame LTC to be reached. Also, its effect on reducing ignition delay helps avoid wall impingement and avoid the combustion to be purely premixed.

Decreasing intake air temperature reduced simultaneously adiabatic flame temperature and equivalence ratio at the lift-off length, contributing to a lower soot formation. Nevertheless, adiabatic flame temperature decrease did not affect $\mathrm{NOx}, \mathrm{HC}, \mathrm{CO}$ and IMEP significantly.

Oxygen concentration was confirmed to be the fundamental to achieve Diffusion-flame LTC. Its intensive reduction is the main cause for adiabatic flame temperature decrease. Despite the fact NOx emissions achieved very low level, its complete extinction did not happen. This effect points to a change in NOx formation mechanism from thermal to prompt. When reducing oxygen concentration, IMEP decreases while HC and CO is kept in very high levels, really unacceptable for a small diesel engine. It occurs due to combustion process deterioration caused by excessive lack of oxygen, reducing global efficiency. The influence of reducing oxygen concentration can be observed on the premixed combustion phase, before flame stabilization. Consequently, there is a reduction in reaction velocity. The slope of RoHR and its peak during premixed combustion tend to reduce. This effect lead to a less intense pressure rise rate and lower combustion noise.

Increasing injection pressure enhances mixing process and reduces $\mathrm{HC}$ and $\mathrm{CO}$. This improvement is also observed on IMEP. On the contrary, the increase of fuel injected before SoC associated to better mixing capability contributes to a more violent and noisier premixed combustion.

Nozzle hydraulic mass flow rate reduction is very effective to achieve Diffusion-flame LTC. Enlarging injection duration increases the time available for the stabilization of a mixing controlled flame. Besides, reducing the amount of delivered fuel before combustion ignition helps reducing combustion noise.

Smaller orifice diameters decrease equivalence ratio at the lift-off length. Consequently, soot precursor formation is reduced, affecting engine-out soot emissions. Mixing process improvement is reflected also in $\mathrm{CO}$ and $\mathrm{HC}$, with slight reduction on their values.

The effects of jet-jet interaction have been observed when using 9x083 $\mu \mathrm{m}$ nozzle. In spite of having the smallest orifice diameter, soot emissions were not the lowest, remaining between the conventional nozzle and the 6x101 $\mu \mathrm{m}$ nozzle. Reducing orifice diameter is a very effective solution, however, if it increases the number of orifices its effect may be cancel or even reversed.

\section{BIBLIOGRAPHY}

[1] Cames M, Helmers E. Critical evaluation of the European diesel car boom - global comparison, environmental effects and various national strategies. Environ Sci Eur 2013;25:15. doi:10.1186/21904715-25-15.

[2] Ambel CC. Europe's tax deals for diesel. vol. 32. 2015. 
[3] Johnson T V. Diesel Emission Control in Review. SAE Int J Fuels Lubr 2008;1:2008-01-0069. doi:10.4271/2008-01-0069.

[4] Johnson T V. Review of Vehicular Emissions Trends. SAE Int J Engines 2015;8:1152-67. doi:10.4271/2015-01-0993.

[5] Glassman I, Yetter RA. Combustion. Elsevier; 2008. doi:10.1016/B978-0-12-088573-2.00025-7.

[6] Dec JE. A Conceptual Model of DI Diesel Combustion Based on Laser-Sheet Imaging*. SAE Tech. Pap., 1997. doi:10.4271/970873.

[7] Musculus MPB, Miles PC, Pickett LM. Conceptual models for partially premixed low-temperature diesel combustion. vol. 39. Elsevier Ltd; 2013. doi:10.1016/j.pecs.2012.09.001.

[8] Kamimoto T, Bae M. High Combustion Temperature for the Reduction of Particulate in Diesel Engines, SAE International; 1988, p. 14. doi:10.4271/880423.

[9] Akihama K, Takatori Y, Inagaki K, Sasaki S, Dean AM. Mechanism of the Smokeless Rich Diesel Combustion by Reducing Temperature. SAE Tech. Pap., vol. 2001, 2001, p. 1-17. doi:10.4271/2001-010655 .

[10] Sandia Corporation. Engine Combustion Research Milestones at the CRF. CRF News 2004;26:2.

[11] Sandia Corporation. Imaging of advanced low-temperatura diesel combustion. CRF News 2005;27:1-6;2.

[12] Tree DR, Svensson KI. Soot processes in compression ignition engines. Prog Energy Combust Sci 2007;33:272-309. doi:10.1016/j.pecs.2006.03.002.

[13] Pickett LM, Siebers DL. Soot Formation in Diesel Fuel Jets Near the Lift-Off Length. Int J Engine Res 2006;7:103-30. doi:10.1243/146808705X57793.

[14] Idicheria CA, Pickett LM. Soot Formation in Diesel Combustion under High-EGR Conditions. SAE Tech Pap 2005:2005-01-3834. doi:10.4271/2005-01-3834.

[15] Bruneaux G. Combustion structure of free and wall-impinging diesel jets by simultaneous laser-induced fluorescence of formaldehyde, poly-aromatic hydrocarbons, and hydroxides. Int J Engine Res 2008;9:24965. doi:10.1243/14680874JER00108.

[16] Pickett LM, López JJ. Jet-Wall Interaction Effects on Diesel Combustion and Soot Formation. SAE 2005 World Congr. Exhib., vol. 2005, SAE International; 2005, p. 1-17. doi:10.4271/2005-01-0921.

[17] Heywood JB. Internal combustion engines fundamentals. 1st editio. McGraw-Hill Education; 1989.

[18] Turns S. Understanding NOx formation in nonpremixed flames: Experiments and modeling. Prog Energy Combust Sci 1995;21:361-85. doi:10.1016/0360-1285(94)00006-9.

[19] Benajes J, Molina S, Novella R, Amorim R. Study on Low Temperature Combustion for Light-Duty Diesel Engines. Energy \& Fuels 2010;24:355-64. doi:10.1021/ef900832c.

[20] Pickett LM, Siebers DL. Non-Sooting, Low Flame Temperature Mixing-Controlled DI Diesel Combustion. SAE Trans., 2004. doi:10.4271/2004-01-1399.

[21] Musculus MPB. Effects of the In-Cylinder Environment on Diffusion Flame Lift-Off in a DI Diesel Engine. SAE Trans., 2003. doi:10.4271/2003-01-0074.

[22] Lapuerta M, Armas O, Hernández JJ. Diagnosis of DI Diesel combustion from in-cylinder pressure signal by estimation of mean thermodynamic properties of the gas. Appl Therm Eng 1999;19:513-29. doi:10.1016/S1359-4311(98)00075-1.

[23] Lapuerta M, Armas O, Bermúdez V. Sensitivity of diesel engine thermodynamic cycle calculation to 
[24] Desantes JM, Arrègle J, Molina S, Lejeune M. Influence of the EGR Rate, Oxygen Concentration and Equivalent Fuel/Air Ratio on the Combustion Behaviour and Pollutant Emissions of a Heavy-Duty Diesel Engine 2000. doi:10.4271/2000-01-1813.

[25] Payri F, Torregrosa AJ, Broatch A, Marant V, Beauge Y, Beauge I. Methodologie d'etude de la qualite du bruit de combustion d'un moteur Diesel automobile a partir de l'analyse de sa pression en cylindre. Acoust Technol 2002;30:25-9.

[26] Payri F, Broatch A, Tormos B, Marant V. New methodology for in-cylinder pressure analysis in direct injection diesel engines - application to combustion noise. Meas Sci Technol 2005;16:540-7. doi:Doi 10.1088/0957-0233/16/2/029.

[27] Bosch W. The Fuel Rate Indicator: A New Measuring Instrument For Display of the Characteristics of Individual Injection, 1966. doi:10.4271/660749.

[28] Pastor J V, Encabo E, Ruiz S. New Modelling Approach For Fast Online Calculations In Sprays, 2000, p. 1-9. doi:10.4271/2000-01-0287.

[29] Christian R, Knopf F, Jasmek A, Schindler W. A new method for ther filter smoke number measurement with provided sensitivity. MTZ Mot Zeitschrift 1993;54:16-22.

[30] JORGE AMORIM R. COMBUSTIÓN POR DIFUSIÓN DE BAJA TEMPERATURA EN MOTORES DIESEL DE PEQUEÑA CILINDRADA. Universitat Politècnica de València, 2010. doi:10.4995/Thesis/10251/8951.

[31] Nakayama S, Fukuma T, Matsunaga A, Miyake T, Wakimoto T. A New Dynamic Combustion Control Method Based on Charge Oxygen Concentration for Diesel Engines, 2003. doi:10.4271/2003-01-3181.

[32] Benajes J V., López JJ, Novella R, García A. Advanced methodology for improving testing efficiency in a single-cylinder research diesel engine. Exp Tech 2008;32:41-7. doi:10.1111/j.1747-1567.2007.00296.x.

[33] Siebers DL. Liquid-phase fuel penetration in diesel sprays. SAE Tech Pap Ser 1998;107:1205-1227. doi:10.4271/1999-01-0528.

[34] García Oliver JM. Aportaciones al estudio del proceso de combustión turbulenta de chorros en motores diesel de inyección directa. Universitat Politècnica de València, 2004. doi:10.4995/Thesis/10251/55164.

[35] Siebers DL, Higgins B. Flame Lift-Off on Direct-Injection Diesel Sprays Under Quiescent Conditions. Sae Trans., vol. 110, 2001, p. 400-421. doi:10.4271/2001-01-0530.

[36] Siebers DL, Higgins B, Pickett L. Flame Lift-Off on Direct-Injection Diesel Fuel Jets: Oxygen Concentration Effects. Sae Trans., 2002, p. 1-22. doi:10.4271/2002-01-0890.

[37] Pickett LM, Siebers DL, Idicheria CA. Relationship Between Ignition Processes and the Lift-Off Length of Diesel Fuel Jets. SAE Tech Pap 2005. doi:10.4271/2005-01-3843.

[38] Siebers DL, Pickett LM. Injection Pressure and Orifice Diameter Effects on Soot in DI Diesel Fuel Jets. In: Whitelaw JH, Payri F, Arcoumanis C, Desantes JM, editors. Thermo- Fluid Dyn. Process. Diesel Engines 2, Berlin, Heidelberg: Springer Berlin Heidelberg; 2004, p. 109-32.

[39] Noehre C, Andersson M, Johansson B, Hultqvist A. Characterization of Partially Premixed Combustion, 2006, p. 776-90. doi:10.4271/2006-01-3412.

[40] Colban WF, Miles PC, Oh S. Effect of Intake Pressure on Performance and Emissions in an Automotive Diesel Engine Operating in Low Temperature Combustion Regimes. SAE Tech Pap 2007:2007-4063. 
702

703

704

705

706

doi:DOI: 10.4271/2007-01-4063.

[41] Pickett LM, Manin J, Genzale CL, Siebers DL, Musculus MPB, Idicheria CA. Relationship Between Diesel Fuel Spray Vapor Penetration/Dispersion and Local Fuel Mixture Fraction. SAE Int J Engines 2011;4:764-99. doi:10.4271/2011-01-0686. 